\title{
Managing Social-Business Tensions: A Review and Research Agenda for Social Enterprise
}

\author{
Wendy K. Smith ${ }^{1}$ \\ University of Delaware
}

\author{
Michael Gonin \\ University of Zurich and University of Lausanne
}

\author{
Marya L. Besharov \\ Cornell University
}

\begin{abstract}
In a world filled with poverty, environmental degradation, and moral injustice, social enterprises offer a ray of hope. These organizations seek to achieve social missions through business ventures. Yet social missions and business ventures are associated with divergent goals, values, norms, and identities. Attending to them simultaneously creates tensions, competing demands, and ethical dilemmas. Effectively understanding social enterprises therefore depends on insight into the nature and management of these tensions. While existing research recognizes tensions between social missions and business ventures, we lack any systematic analysis. Our paper addresses this issue. We first categorize the types of tensions that arise between social missions and business ventures, emphasizing their prevalence and variety. We then explore how four different organizational theories offer insight into these tensions, and we develop an agenda for future research. We end by arguing that a focus on social-business tensions not only expands insight into social enterprises, but also provides an opportunity for research on social enterprises to inform traditional organizational theories. Taken together, our analysis of tensions in social enterprises integrates and seeks to energize research on this expanding phenomenon.
\end{abstract}

KEY WORDS: social enterprise, social entrepreneur, paradox theory, institutional theory, stakeholder theory, organizational identity, hybrid organizations

OCIAL ENTERPRISE RESEARCH has become increasingly crowded. Only several years ago, a handful of colleagues urged scholars to take social enterprises seriously (Dees, 2007; Seelos \& Mair, 2007). Academics responded and organized conferences (e.g., NYU Satter Conference on Social Entrepreneurship), created special issues (e.g., Journal of Business Ethics, 2012; Academy of Management Learning and Education, 2012), and launched a dedicated journal (Journal of 
Social Entrepreneurship, established in 2010). This flurry of activity has informed our theoretical understanding, provided empirical evidence, and converged on definitions and boundary conditions.

One insight emerging from the expanding research on social enterprises centers on tensions within these organizations (Smith, Besharov, Wessels, \& Chertok, 2012; Tracey \& Phillips, 2007). Social enterprises seek to solve social problems through business ventures. They combine the efficiency, innovation, and resources of a traditional for-profit firm with the passion, values, and mission of a not-for-profit organization (Battilana, Lee, Walker, \& Dorsey, 2012). As a result, they embed within the boundaries of one organization multiple and inconsistent goals, norms, and values, creating contradictory prescriptions for action (Besharov \& Smith, 2013) and generating ethical dilemmas for their leaders (Dees, 2012; Margolis \& Walsh, 2003). Effectively understanding social enterprises depends on insight into the nature and management of these tensions. Yet, while existing research points to social-business tensions as a key characteristic of social enterprises, we know less about their different types, their associated challenges, and the nature of organizational responses to these challenges. As a result, our scholarship does not yet fully capture the complexity of the social enterprise phenomenon.

We address this issue in this paper. Our goal is to expand our understanding of social enterprises by focusing on the nature and management of tensions in these organizations. To do so, we first review the empirical literature on social enterprises, drawing from Smith and Lewis's (2011) typology to categorize these tensions as performing, organizing, belonging, and learning. Our review emphasizes both the prevalence and variety of tensions. Second, we consider how existing organizational theories explain the nature and management of these tensions. In line with other multi-theoretical approaches to social enterprises (Dacin, Dacin, \& Tracey, 2011; Dacin, Dacin, \& Matear, 2010; Mair \& Martí, 2006), we organize this section around four theories previous applied to this phenomenon-institutional theory, organizational identity, stakeholder theory, and paradox theory. Our analysis of these theoretical lenses shows how they can provide robust insights into social enterprises and identifies critical issues for further research within each perspective. Finally, in our discussion section, we explore how this line of inquiry into tensions in social enterprises not only draws on traditional organizational theories, but can in turn inform these same theories. Taken together, our review and analysis of socialbusiness tensions expands insight into and from social enterprises.

\section{TENSIONS WITHIN SOCIAL ENTERPRISES}

Jeremy Hockenstein traveled to Siem Reap, Cambodia, in 1999 to visit the Angkor Wat temples. While he was there, he was surprised by the number of impoverished, but eager, Cambodians clamoring into small internet cafes to access a broader world through their computer screens. This observation ultimately led him to establish what has become an internationally acclaimed social enterprise, Digital Divide Data, which seeks to break the cycle of poverty by providing economically and physically disadvantaged people economic opportunities through training and employment in 
a labor-intensive information technology firm (Smith, Leonard, \& Epstein, 2007). Now over ten years old, Digital Divide Data has improved the lives of more than 1,500 employees in Cambodia, Laos, and Kenya.

Digital Divide Data's story is one of many examples of the growing phenomenon of social enterprises - organizations that use business ventures to achieve a social mission. Social enterprises adopt a wide range of strategies for addressing problems and opportunities in society (Alter, 2008). Digital Divide Data exemplifies social enterprises that focus on advancing social welfare through employment. These "work integration" organizations seek social improvement by offering skill development, training, and salaries that help marginally employable citizens achieve continued employment (Battilana, Pache, Sengul, \& Model, 2011; Tracey, Phillips, \& Jarvis, 2011). Other organizations seek to improve human and environmental welfare through their products, processes, and services. For example, the Cambridge Energy Alliance provides goods and services to increase energy efficiency (Jay, 2013). Fair trade organizations shift power and resources to improve market conditions for those producing goods in developing countries (Nicholls \& Opal, 2004). Still other organizations offer opportunities for a disadvantaged market segment, providing goods and services to previously disenfranchised customers. For example, microfinance organizations began by making financial instruments and access to capital available to people with limited resources (Mair \& Martí, 2009; Yunus, 1999). New organizations are rethinking their manufacturing and designs to provide goods to people at the "bottom of the pyramid" who live on less than $\$ 1$ per day (Prahalad, 2006). For example, Essilor, a global optical lens industry, shifted the nature and distribution of its lenses to make them accessible and affordable to people in rural India with otherwise limited access (Karnani, Garrette, Kassalow, \& Lee, 2011).

Despite the variety of types, a unifying characteristic of these organizations is the multiple and often conflicting demands that surface through their commitments to both social missions and business ventures. These commitments juxtapose divergent identities, goals, logics, and practices, which creates tensions for leaders and their organizations. While many authors explicitly or implicitly address these tensions as a core characteristic of social enterprises, the literature provides no systematic analysis of how these tensions manifest. In this section, we review extant research to describe and categorize tensions within social enterprises. To do so, we follow Smith and Lewis's (2011) categorization of tensions as performing, organizing, belonging, and learning. We emphasize the prevalence and variety of tensions within social enterprises, while also noting the critical challenges that emerge from these tensions. Table 1 (next page) provides a summary.

\section{Performing}

Performing tensions surface as organizations seek varied and conflicting goals or strive to address inconsistent demands across multiple stakeholders (Smith \& Lewis, 2011). The goals associated with a social mission center on making a difference. A broad range of stakeholders stand to benefit from the success of a social mission, including but not limited to employees, beneficiaries, communities, families, and 
Table 1: Social-Business Tensions within Social Enterprises

\begin{tabular}{|c|c|c|c|}
\hline Type of Tensions & $\begin{array}{l}\text { Dimensions of } \\
\text { Social Missions }\end{array}$ & $\begin{array}{l}\text { Dimensions of } \\
\text { Business Ventures }\end{array}$ & $\begin{array}{l}\text { Emergent Tensions be- } \\
\text { tween Social Missions } \\
\text { and Business Ventures }\end{array}$ \\
\hline $\begin{array}{l}\text { Performing Tensions } \\
\text { Tensions that emerge } \\
\text { from divergent } \\
\text { outcomes-such as } \\
\text { goals, metrics, and } \\
\text { stakeholders }\end{array}$ & $\begin{array}{l}\text { - Goals address concerns } \\
\text { across a broad eco- } \\
\text { system of stakeholders } \\
\text { - Metrics are more sub- } \\
\text { jective, qualitative, and } \\
\text { difficult to standardize } \\
\text { and compare across } \\
\text { organizations }\end{array}$ & $\begin{array}{l}\text { - Goals address concerns } \\
\text { of a narrow group of } \\
\text { shareholders } \\
\text { - Metrics are more objec- } \\
\text { tive, quantitative and } \\
\text { easier to standardize } \\
\text { and compare across } \\
\text { organizations }\end{array}$ & $\begin{array}{l}\text { - How do organizations } \\
\text { and leaders define suc- } \\
\text { cess across divergent } \\
\text { goals, particularly as the } \\
\text { same event can simulta- } \\
\text { neously be a success in } \\
\text { one domain and failure } \\
\text { in the other? } \\
\text { - How can organizations } \\
\text { sustain support for both } \\
\text { social and financial } \\
\text { metrics? }\end{array}$ \\
\hline $\begin{array}{l}\text { Organizing Tensions } \\
\text { Tensions that emerge } \\
\text { from divergent inter- } \\
\text { nal dynamics-such } \\
\text { as structures, cultures, } \\
\text { practices, and pro- } \\
\text { cesses }\end{array}$ & $\begin{array}{l}\text { - Organizations hire } \\
\text { for skills that enable } \\
\text { the social mission, or } \\
\text { hire disadvantaged } \\
\text { employees as a means } \\
\text { of achieving the social } \\
\text { mission } \\
\text { - Organizations usually } \\
\text { adopt non-profit legal } \\
\text { form }\end{array}$ & $\begin{array}{l}\text { - Organizations hire for } \\
\text { skills that enable effi- } \\
\text { ciency and profitability } \\
\text { - Organizations usually } \\
\text { adopt for-profit legal } \\
\text { form }\end{array}$ & $\begin{array}{l}\text { - Who should organiza- } \\
\text { tions hire, and how } \\
\text { can they socialize } \\
\text { employees? } \\
\text { - How much should orga- } \\
\text { nizations differentiate } \\
\text { vs. integrate the social } \\
\text { mission and the busi- } \\
\text { ness venture? } \\
\text { - What legal designation } \\
\text { should organizations } \\
\text { adopt? }\end{array}$ \\
\hline $\begin{array}{l}\text { Belonging Tensions } \\
\text { Tensions that emerge } \\
\text { from divergent } \\
\text { identities among sub- } \\
\text { groups, and between } \\
\text { subgroups and the } \\
\text { organization }\end{array}$ & $\begin{array}{l}\text { Employees and stake- } \\
\text { holders predominantly } \\
\text { identify with the social } \\
\text { mission }\end{array}$ & $\begin{array}{l}\text { - Employees and stake- } \\
\text { holders predominantly } \\
\text { identify with the busi- } \\
\text { ness venture }\end{array}$ & $\begin{array}{l}\text { - How can organiza- } \\
\text { tions manage divergent } \\
\text { identity expectations } \\
\text { among subgroups of } \\
\text { employees? } \\
\text { - How can organizations } \\
\text { manage divergent iden- } \\
\text { tity expectations among } \\
\text { stakeholder groups? } \\
\text { - How can organizations } \\
\text { present their hybrid } \\
\text { social-business identity } \\
\text { to external audiences? }\end{array}$ \\
\hline $\begin{array}{l}\text { Learning Tensions } \\
\text { Tensions of growth, } \\
\text { scale, and change that } \\
\text { emerge from divergent } \\
\text { time horizons }\end{array}$ & $\begin{array}{l}\text { - Social mission success } \\
\text { requires a long time } \\
\text { horizon } \\
\text { - Growth can increase } \\
\text { but also threaten social } \\
\text { mission impact }\end{array}$ & $\begin{array}{l}\text { - Business venture suc- } \\
\text { cess can come from } \\
\text { short-term gains } \\
\text { - Social mission can } \\
\text { constrain growth }\end{array}$ & $\begin{array}{l}\text { - How can organizations } \\
\text { attend to both the short } \\
\text { term and long term? } \\
\text { - How can organiza- } \\
\text { tions manage increased } \\
\text { short-term costs to } \\
\text { achieve long-term } \\
\text { social expansion? }\end{array}$ \\
\hline
\end{tabular}

funding partners (Grimes, 2010; Haigh \& Hoffman, 2012; Hanleybrown, Kania, \& Kramer, Forthcoming). Evaluating progress toward these goals frequently involves qualitative, ambiguous, and non-standardized metrics (Ebrahim \& Rangan, 2010; Epstein, 2008), creating challenges for measuring and comparing social mission success. For example, organizations whose mission is to help severely disadvantaged people find better opportunities through employment do not measure their success only by the number of people they employ, but also by the extent to which they are able to enhance the self-esteem, health, social status, family stability, and subjective well-being of these individuals. In contrast to the goals associated with 
social missions, those associated with business ventures involve commercial success and profitability. They can be measured with specific, qualitative, and standardized metrics, and they address a narrower group of stakeholders, specifically owners and investors (Jensen, 2002).

These divergent goals, metrics, and stakeholders create several conflicting demands and performing tensions in social enterprises. One critical challenge involves how to define success across contradictory goals. This question becomes particularly complex when success in one domain is considered failure in another. For example, Jay's (2013) analysis of the Cambridge Energy Alliance shows how outcomes which are considered successes for the organization's social mission simultaneously reflect failures for their financial goals, and vice versa. Tracey, Phillips, and Jarvis (2011) show how efforts to expand social impact at Aspire, a work integration organization, ultimately led to financial failure, but in the process launched a successful movement of other work integration organizations that could sustain Aspire's broader social objectives.

Performing tensions also surface in questions about how to sustain commitments to conflicting goals over time. Research suggests that in the context of competing metrics, one tends to dominate. In particular, as behavioral decision making theory demonstrates, we tend to emphasize metrics that are more quantifiable, clear, and short-term oriented over those that are more qualitative, ambiguous, uncertain, and long-term oriented (Levinthal \& March, 1993). Quantifiable metrics offer clarity and focus to situations that might otherwise be ambiguous and uncertain, and in doing so they can foster collective trust (Porter, 1995) and commitment to strategic action (Denis, Langley, \& Rouleau, 2006). In the context of social enterprises, a preference for quantifiable metrics can lead business objectives to become dominant. At the same time, the passion and commitment of social entrepreneurs can lead to dominance of the social mission. Social entrepreneurs often create their organizations because of a deep commitment to the social mission (Bornstein, 2004), which provides critical inspiration, focus, and motivation. In the extreme, however, these entrepreneurs sometimes emphasize the mission's success and expansion to the detriment of the business purpose, leading to organizational demise. The experience of Aspire, the British work integration organization described above (Tracey et al., 2011), illustrates how prioritizing social mission can lead to financial ruin.

\section{Organizing}

Organizing tensions emerge through commitments to contradictory organizational structures, cultures, practices, and processes (Smith \& Lewis, 2011). Social missions and business ventures frequently involve different, and inconsistent, cultures and human resource practices. They often require different employee profiles, for example, raising tensions about who to hire and how to socialize employees. Battilana and Dorado (2010) demonstrate such organizing tensions in their research on microfinance. As they show, effectively selling financial products to previously disenfranchised people requires interpersonal skills to help clients address emotional, social, and psychological barriers. These skills often are associated with people 
trained in social work and psychology backgrounds. In contrast, developing and managing the financial nature of these products depends on quantitative analysis skills traditionally developed in business schools. As a result, microfinance organizations grapple with who to hire. Work integration social enterprises also face organizing tensions in hiring. These organizations create businesses that provide training and work experience to disadvantaged people, enabling them to gain or improve employment opportunities. This creates tensions about who to hire-people who are severely disadvantaged or people with skills that are needed for the success of the business. Digital Divide Data, for example, initially hired several cohorts of girls rescued from sex trafficking, seeking to help them find alternative employment and avoid the risk of returning to the sex trade. Yet the girls' limited technical skills, and the difficulty of training and socializing them within the existing culture, resulted in significant costs to the organization (Smith et al., 2007).

Social enterprises also face organizing tensions around questions of organizational structure and legal form. For example, should they create separated or integrated structures, practices, and roles for pursuing their social mission and their business venture? They must also decide whether to adopt a for-profit or not-for-profit legal form (Battilana et al., 2012). Some organizations overcome this challenge by creating two distinct legal entities, a for-profit organization that pursues commercial activities and a not-for-profit organization that carries out the social mission (Bromberger, 2011). Other organizations adopt hybrid legal forms that formally acknowledge the organization's double or triple bottom line (Battilana et al., 2012; Haigh \& Hoffman, 2012).

\section{Belonging}

Belonging tensions involve questions of identity (Smith \& Lewis, 2011). Attending to both a social mission and a business venture raises belonging tensions, as leaders struggle to articulate "who we are" and "what we do" both individually and collectively. For example, leaders face questions from employees about whether the organization is more aligned with its profit motive or its social mission (Tracey \& Phillips, 2007). Moreover, when leaders or members experience a sense of belonging or identification with different organizational goals and values, this can create subgroups and generate internal conflict. For example, Battilana and Dorado (2010) find that hiring individuals with distinct commercial and social welfare backgrounds led deep fault lines to develop within the BancoSol microfinance organization and ultimately fueled intractable conflict.

Belonging tensions also surface as social enterprises manage relationships with stakeholders. Stakeholders aligned with the social mission, such as foundations, donors, and non-profit organizations, often have identities that diverge from those aligned with the business venture, including customers, investors, suppliers. While all these stakeholders may value the combined social and business purposes of a social enterprise, they also seek to connect with the organization through their particular identities. How then, can social enterprises position themselves vis-à-vis their divergent stakeholders? They must decide whether and when to emphasize 
their social mission, their business venture, or both simultaneously. Digital Divide Data initially addressed this challenge by presenting different identities to different stakeholder groups. This strategy was effective in isolated encounters, but challenges arose when messages intended for one stakeholder group were visible as well to members of other groups. For example, when Digital Divide Data emphasized its social mission in marketing materials on the company website, employees, who are the main beneficiaries of this mission, responded with accusations of exploitation. Emphasizing both social and business goals simultaneously also poses challenges. In Every Language, a professional translation business hiring primarily immigrants with degrees in translation and in their mother tongue, attempts to systematically communicate an integrated social and business identity (Bell, 2011). As a result, traditional businesses doubt that the organization's work quality meets "business standards," while traditional not-for-profits worry about the possible exploitation of immigrant workers. These examples reveal the belonging tensions that arise in social enterprises, whether they define themselves through multiple differentiated identities or adopt an integrated hybrid identity.

\section{Learning}

Tensions of learning emerge from the juxtaposition of multiple time horizons, as organizations strive for growth, scale, and flexibility over the long term, while also seeking stability and certainty in the short term (Smith \& Lewis, 2011). For social enterprises, these tensions surface in several domains. First, financial outcomes such as profits, revenues, and costs can easily be measured in the short term, whereas social mission outcomes such as alleviating poverty, increasing literacy, or overcoming economic injustice, often require a long time horizon (Hoffman, Badiane, \& Haigh, 2010). These different time horizons can drive conflicting prescriptions for strategic action. For example, in work integration social enterprises, the short-term goals of producing quality work outcomes, meeting client needs, and finding employees future jobs can conflict with longer term goals of generating skills for sustained and stable employment (Smith et al., 2007). At Digital Divide Data, leaders debated whether to invest in better computers and hardware to improve efficiency and meet the immediate needs of clients and investors or to invest in better healthcare services to improve workers' wellbeing over the long term. They also discussed the tradeoffs involved in opening offices in rural areas of Cambodia. Doing so would provide employment for the country's most disadvantaged people, helping the organization accomplish its social mission, but it would also create productivity challenges in the short term, leading one executive to refer to the idea as a "thatched hut dream," while another termed it a "thatched hut nightmare."

Social enterprises further face learning tensions around growth and scalability. Social enterprises want to expand in order to increase the impact of their mission (Dees, Battle Anderson, \& Wei-Skillern, 2004). However growth can simultaneously threaten the mission's impact, as factors that facilitate the social mission in small organizations diminish with size. In particular, local ties, communal trust-building, and imprinting of the founder's values and morals all contribute to the values and 
mission of smaller organizations (Haigh \& Hoffman, 2012). Organizational growth minimizes the impact of these factors, introducing possibilities for mission drift and value violations. For example, local cooperatives depend on connections and identification with the community, which become harder to foster as these organization grow (Foreman \& Whetten, 2002). Many microfinance organizations face this issue as well, as their model depends on the trust built through local connections in order to succeed (Yunus, 1999). Moreover, social enterprises often depend on participatory forms of government, which are more challenging to sustain as organizations grow in size (Defourny \& Nyssens, 2010). In other cases, growth can increase social mission costs. Digital Divide Data, for example, initially supported employees' education through grants. However, fully supporting employee education prohibited Digital Divide Data from scaling their business. In order to effectively grow, leaders therefore had to develop alternative means of implementing and funding their commitment to supporting employees' education, for example by offering loans rather than outright grants.

Taken together, our review of the literature suggests social enterprises experience prevalent and persistent tensions between social missions and business ventures. These tensions emerge across varied domains, and they remain salient over time. Even as leaders make decisions in response to a specific challenge, underlying tensions, inconsistencies, and competing demands remain. Indeed, as Tracey and Phillips (2007) note, "conflict . . is a central characteristic of social enterprises" (267). Effectively understanding social enterprises therefore requires insight into these persistent tensions and their management. In the next section, we discuss four existing theoretical approaches for doing so.

\section{THEORETICAL PERSPECTIVES ON TENSIONS WITHIN SOCIAL ENTERPRISES}

To understand the nature and management of tensions within social enterprises, we follow others in applying existing theoretical lenses to this phenomenon, rather than treating social enterprise as a distinct theoretical domain (Dacin et al., 2010). We draw on four theoretical lenses that are particularly relevant for understanding the tensions that emerge between social missions and business ventures: institutional theory, organizational identity, stakeholder theory, and paradox theory. First, institutional theory observes that distinct societal logics are associated with social missions and business ventures (Battilana \& Dorado, 2010; Tracey et al., 2011). We explore how institutional theory informs our understanding of societal influences on social-business tensions and their management. Second, research in organizational identity distinguishes between the normative and utilitarian identities of social enterprises (Albert \& Whetten, 1985; Moss, Short, Payne, \& Lumpkin, 2011). We consider the insights this lens offers into how divergent identities influence organizational action. Third, stakeholder theory illuminates how distinct needs of external stakeholders create pressures on organizations to attend to both social and financial outcomes (Donaldson \& Preston, 1995). We explore how stakeholder theory offers both justification for and managerial insight into attending to these conflicting goals. 
Finally, paradox theory posits that tensions, such as those between social missions and business ventures, are inherent within organizations (Smith et al., 2012; Smith \& Lewis, 2011). We explore how this lens offers insight into to the nature and management of these tensions. By analyzing existing research on tensions in social enterprises through each of these theoretical lenses and by proposing questions for future research, we set out an agenda for extending our understanding of these organizations. We discuss this agenda in detail below and summarize it in Table 2.

\section{Institutional Theory}

Institutional theory focuses on the relationship between organizations and their environments, thereby offering insight into tensions of performing and organizing within social enterprises. This theoretical perspective explores factors associated with the emergence and survival of institutions and the processes by which they

Table 2: A Research Agenda for Exploring Tensions within Social Enterprises

\begin{tabular}{|c|c|c|c|c|}
\hline $\begin{array}{c}\text { Theoretical } \\
\text { Lens }\end{array}$ & $\begin{array}{c}\text { Primary } \\
\text { Theoretical } \\
\text { Questions }\end{array}$ & $\begin{array}{l}\text { Relevant Articles } \\
\text { on } \\
\text { Social Enterprises }\end{array}$ & $\begin{array}{c}\text { Representative } \\
\text { Findings on } \\
\text { Tensions in Social } \\
\text { Enterprises }\end{array}$ & $\begin{array}{l}\text { Future Research } \\
\text { Questions on } \\
\text { Tensions in Social } \\
\text { Enterprises }\end{array}$ \\
\hline $\begin{array}{l}\text { Institutional } \\
\text { Theory }\end{array}$ & $\begin{array}{l}\text { - What enables } \\
\text { the creation, } \\
\text { maintenance, and } \\
\text { destruction of } \\
\text { institutions? } \\
\text { - How do societal- } \\
\text { level institutions } \\
\text { inform organiza- } \\
\text { tional action? } \\
\text { - How do organiza- } \\
\text { tions that embed } \\
\text { multiple institu- } \\
\text { tional logics gain } \\
\text { legitimacy? }\end{array}$ & $\begin{array}{l}\text { - Batilana \& Do- } \\
\text { rado, } 2010 \\
\text { - Pache \& Santos, } \\
2010 \\
\text { - Tracey, Phillips, \& } \\
\text { Jarvis, 2011 }\end{array}$ & $\begin{array}{l}\text { - Hiring employ- } \\
\text { ees who hold } \\
\text { neither logic and } \\
\text { socializing them to } \\
\text { hold both is more } \\
\text { effective than hiring } \\
\text { employees who } \\
\text { carry one logic or } \\
\text { the other. } \\
\text { - Selective coupling } \\
\text { of practices from } \\
\text { each logic can } \\
\text { enable organiza- } \\
\text { tions to sustain both } \\
\text { logics } \\
\text { - Organizational } \\
\text { structures that bal- } \\
\text { ance differentiation } \\
\text { and integration can } \\
\text { support competing } \\
\text { logics. }\end{array}$ & $\begin{array}{l}\text { - How do societal } \\
\text { institutions impact } \\
\text { social enterprises' } \\
\text { ability gain legiti- } \\
\text { macy and sustain } \\
\text { hybridity? } \\
\text { - How do societal in- } \\
\text { stitutions impact the } \\
\text { salience of different } \\
\text { types of tensions } \\
\text { that emerge in } \\
\text { social enterprises? } \\
\text { - What is the role } \\
\text { of agency in } \\
\text { the creation of } \\
\text { organizations and } \\
\text { institutions that } \\
\text { combine social } \\
\text { welfare and com- } \\
\text { mercial logics? }\end{array}$ \\
\hline $\begin{array}{l}\text { Organizational } \\
\text { Identity }\end{array}$ & $\begin{array}{l}\text { - What is the nature } \\
\text { of organizational } \\
\text { identity? } \\
\text { - How do organi- } \\
\text { zational identities } \\
\text { change? } \\
\text { - How do organiza- } \\
\text { tions manage } \\
\text { multiple identi- } \\
\text { ties? }\end{array}$ & $\begin{array}{l}\text { - Moss, Short, } \\
\text { Payne, \& Lump- } \\
\text { kin, } 2011 \\
\text { - Ashforth, Re- } \\
\text { ingen, \& Ward, } \\
2013 \\
\text { - Besharov, } 2013\end{array}$ & $\begin{array}{l}\text { - Creating an integra- } \\
\text { tive organizational } \\
\text { identity, together } \\
\text { with distinct } \\
\text { subgroup identi- } \\
\text { ties, can mitigate } \\
\text { conflict and foster } \\
\text { positive identifica- } \\
\text { tion. } \\
\text { - Promoting pluralist } \\
\text { members, develop- } \\
\text { ing integrative } \\
\text { solutions, and } \\
\text { enshrining social } \\
\text { mission into } \\
\text { required work pro- } \\
\text { cedures can address } \\
\text { belonging tensions } \\
\text { among social enter- } \\
\text { prise members. }\end{array}$ & $\begin{array}{l}\text { - How can social } \\
\text { enterprises effec- } \\
\text { tively manage their } \\
\text { multiple identities? } \\
\text { - How do social } \\
\text { enterprises present } \\
\text { their multiple iden- } \\
\text { tities to external } \\
\text { stakeholders? } \\
\text { - How do social en- } \\
\text { terprises' identities } \\
\text { change over time, } \\
\text { and how does this } \\
\text { impact the manage- } \\
\text { ment of tensions? }\end{array}$ \\
\hline
\end{tabular}




\begin{tabular}{|c|c|c|c|c|}
\hline $\begin{array}{c}\text { Theoretical } \\
\text { Lens }\end{array}$ & $\begin{array}{c}\text { Primary } \\
\text { Theoretical } \\
\text { Questions }\end{array}$ & $\begin{array}{l}\text { Relevant Articles } \\
\text { on } \\
\text { Social Enterprises }\end{array}$ & $\begin{array}{c}\text { Representative } \\
\text { Findings on } \\
\text { Tensions in Social } \\
\text { Enterprises }\end{array}$ & $\begin{array}{l}\text { Future Research } \\
\text { Questions on } \\
\text { Tensions in Social } \\
\text { Enterprises }\end{array}$ \\
\hline $\begin{array}{l}\text { Stakeholder } \\
\text { Theory }\end{array}$ & $\begin{array}{l}\text { - To whom are } \\
\text { businesses ac- } \\
\text { countable? } \\
\text { - How do managers } \\
\text { balance duties to } \\
\text { shareholders with } \\
\text { those to other } \\
\text { stakeholders? } \\
\text { - On which stake- } \\
\text { holders should } \\
\text { managers focus? }\end{array}$ & $\begin{array}{l}\text { - Cooney, } 2012 \\
\text { • Haigh \& Hoffman, } \\
2012 \\
\text { • Kania \& Kramer, } \\
2011\end{array}$ & $\begin{array}{l}\text { - Social entrepre- } \\
\text { neurs bring together } \\
\text { stakeholders with } \\
\text { divergent back- } \\
\text { grounds and values. } \\
\text { - Social enterprise } \\
\text { success depends on } \\
\text { collaborations with } \\
\text { multiple stakehold- } \\
\text { ers. } \\
\text { - Legal forms for so- } \\
\text { cial enterprises vary } \\
\text { in the legitimacy } \\
\text { they afford to dif- } \\
\text { ferent stakeholders. }\end{array}$ & $\begin{array}{l}\text { - How and when can } \\
\text { relations with diver- } \\
\text { gent stakeholders } \\
\text { contribute to social } \\
\text { enterprise success? } \\
\text { - To what extent are } \\
\text { social enterprises } \\
\text { legitimate actors } \\
\text { within their com- } \\
\text { munity? } \\
\text { - Under what condi- } \\
\text { tions might social } \\
\text { enterprises harm } \\
\text { stakeholders they } \\
\text { claim to support? }\end{array}$ \\
\hline Paradox Theory & $\begin{array}{l}\text { - How do para- } \\
\text { doxical tensions } \\
\text { surface in organi- } \\
\text { zations? } \\
\text { - How can leaders } \\
\text { and organizations } \\
\text { manage para- } \\
\text { doxical tensions in } \\
\text { organizations? }\end{array}$ & $\begin{array}{l}\text { - Jay, } 2012 \\
\text { - Smith, Besharov, } \\
\text { Wessels, \& Cher- } \\
\text { tok, } 2012\end{array}$ & $\begin{array}{l}\text { - Leaders experience } \\
\text { social enterprises as } \\
\text { paradoxical. } \\
\text { - Tensions between } \\
\text { social missions and } \\
\text { business purposes } \\
\text { are not only con- } \\
\text { tradictory, but also } \\
\text { reinforcing. } \\
\text { - Long term } \\
\text { organizational } \\
\text { success depends on } \\
\text { embracing, rather } \\
\text { than resolving } \\
\text { paradoxes. }\end{array}$ & $\begin{array}{l}\text { - What paradoxical } \\
\text { tensions are most } \\
\text { salient in social } \\
\text { enterprises? } \\
\text { - What organizational } \\
\text { and characteristics } \\
\text { enable social enter- } \\
\text { prises to effectively } \\
\text { embrace paradoxi- } \\
\text { cal tensions? }\end{array}$ \\
\hline
\end{tabular}

come to be seen as legitimate. Organizations gain legitimacy by aligning with social rules, norms, and values, which affords them status and access to resources (Meyer \& Rowan, 1977). Early institutional scholars emphasized that "complete legitimacy" required creating internal clarity and coherence within organizations to align with external stakeholders (Meyer \& Rowan, 1977). Attending to conflicting demands was thought to diminish alignment, fostering instability and ultimately threatening survival (DiMaggio \& Powell, 1983). Yet, as recent research suggests, most environments are characterized by institutional pluralism and complexity (Greenwood, Raynard, Kodeih, Micelotta, \& Lounsbury, 2011; Kraatz \& Block, 2008), such that they impose competing institutional demands on organizations (Pache \& Santos, 2010).

Research on pluralism, complexity, and competing demands draws on the idea of institutional logics, defined as sets of material practices, values, beliefs, and norms (Thornton, Ocasio, \& Lounsbury, 2012). Logics establish "the rules of the game" at the societal level, which shape beliefs and behavior within organizations. Individually, institutional logics are internally consistent and offer coherent prescriptions for action. In combination, however, multiple logics present varied and often incompatible prescriptions, leading to uncertainty, contestation, and conflict (Greenwood et al., 2011; Pache \& Santos, 2010; Thornton, 2002). Institutional scholars refer to organizations that embed such competing logics within their core 
features as "hybrids" (Besharov \& Smith, 2013). Social enterprises are hybrids that embed conflicting social welfare and commercial logics (Battilana \& Dorado, 2010; Battilana et al., 2012). A social welfare logic focuses on improving the welfare of society, whereas a commercial logic stresses profit, efficiency, and operational effectiveness. Each logic is represented and supported by distinct institutional structures. Whereas a social welfare logic is associated with philanthropic actors and a non-profit legal form, a commercial logic relies on earned revenues and a for-profit legal form (Battilana et al., 2012).

Being at the crossroads of distinct logics can be advantageous, as the juxtaposition of conflicting demands affords leaders greater latitude in developing novel, creative alternatives to existing institutional arrangements (Seo \& Creed, 2002; Tracey et al., 2011). Indeed, entrepreneurs may purposefully seek to engage conflicting logics as a means of building new organizational forms (DiMaggio, 1988; Thornton et al., 2012). For example, in their analysis of how a social enterprise emerged to fill an institutional void - an area not covered by existing institutions-Mair and colleagues (Mair \& Martí, 2009; Mair, Martí, \& Ventresca, 2012) emphasize the role of agency and entrepreneurship. However, being at an institutional crossroads also creates significant challenges for social enterprises and their leaders, as it can be difficult to sustain commitments to competing logics. In order to attain needed resources, social enterprises may respond to institutional demands stemming from a commercial logic while failing to attend to those associated with a social welfare logic (Battilana, Pache, Sengul, \& Model, 2013; Pfeffer \& Salancik, 1978). A number of organizations initiated as social enterprises, for example, have shifted to prioritize their business venture over their social mission (see Grimes, 2010). The field of microfinance illustrates this tendency, as several prominent organizations have drifted away from their initial social mission in search of increased revenues (Mersland \& Strom, 2010; Yunus, 2010). One challenge for social enterprises, therefore, is to sustain commitments to both social welfare and commercial logics amidst institutional pressure to prioritize the latter.

One stream of institutional research addresses this question by exploring internal organizational responses to competing institutional demands. For example, Pache and Santos (2010) elaborate five different strategies for attending to competing institutional demands -acquiescence, compliance, defiance, avoidance, and manipulation. They propose that the likelihood of pursuing a particular strategy depends on the internal representation of competing demands and on whether tensions between these demands involve goals or means. Battilana and Dorado (2010) emphasize leadership and managerial discretion in explaining organizational responses to competing demands. They compare two microfinance organizations facing similar institutional environments that adopted different hiring and socialization practices to respond to tensions between commercial and social welfare logics. One organization hired candidates with backgrounds in either banking or social work, leading to the emergence of fault lines and intractable conflict between employees who supported the commercial mission and those who supported the social mission. In contrast, a second organization hired applicants with neither background and socialized them to support an integrated mission of operational excellence. This approach enabled 
the organization to thrive financially while also accomplishing its social mission, thereby sustaining both commercial and social welfare logics. Other studies emphasize the role of organizations in creating specific metrics for measuring social performance (Battilana et al., 2013; Ebrahim \& Rangan, 2010), which can offset the pressures to prioritize market demands. Finally, a recent multiple case study of French work integration organizations shows how selectively coupling practices associated with commercial and social welfare logics, rather than decoupling these practices or seeking to find compromises between them, can enable social enterprises to sustain both logics over time (Pache \& Santos, Forthcoming).

Scholars have also explored the characteristics of institutional actors who generate and sustain social enterprises (Zahra, Gedajlovic, Neubaum, \& Shulman, 2009). These studies suggest that creating social enterprises that accommodate divergent logics not only requires entrepreneurs with an exceptional commitment to and passion for the social mission (Bornstein, 2004; Dees, 2001) and an ethic of care to sustain the focus on social welfare (Pache, 2013), but also individuals who have the ability to manage contradictory demands that emerge from multiple logics (Smith et al., 2012), including a capacity for counterfactual or paradoxical thinking (Tracey et al., 2011).

Institutional theory further offers insights into organizing tensions in social enterprises by considering designs and structures that enable competing logics to coexist. Besharov and Smith (2013) argue that competing logics within organizations can lead to intractable conflict between subgroups that embrace each perspective or to one logic dominating the other. They suggest that sustaining competing logics within productive tension depends on creating structures that both differentiate and integrate logics. Differentiation may involve distinct subgroups, or at the extreme, the establishment of two legal entities - a for-profit and a not-for-profit. Differentiation may also surface through distinct roles among leaders and board members, as well as separate metrics and reporting systems for social and business outcomes. Differentiation enables organizations to highlight and attend to the distinct needs of a social mission and a business venture. However, as Besharov and Smith (2013) argue, differentiation can lead to intractable conflict, if not offset by integrative forces, such as an overarching vision or an integrated leadership team or board of directors.

An institutional perspective offers a number of promising directions for future research on tensions in social enterprises. First, institutional theory can provide insight about how social enterprises that embed competing logics gain legitimacy in a broader societal context. Social enterprises emerged as organizations associated with divergent logics and supported by distinct sets of institutional actors. However, as social enterprises grow in number and influence, so too do societallevel institutions that similarly embody both social welfare and commercial logics. For example, in many countries there is now a designated legal status for pursuing a double or triple bottom line, such as low-profit limited liability companies or a benefit corporations in the United States (Bromberger, 2011), community interest companies in the United Kingdom (Haugh \& Peredo, 2010; Snaith, 2007), and social cooperatives in Italy (Borzaga \& Santuari, 2001). Philanthropic actors such as Skoll, Ashoka, and Echoing Green provide targeted funding for social enterprises, while creating communities and networks of like-minded entrepreneurs. Universities 
that previously ignored the phenomenon now offer courses and have built research centers dedicated to social entrepreneurship (Smith et al., 2012; Tracey \& Phillips, 2007). The emergence of such societal-level institutions, which appear to have hybrid or integrative interests, can legitimate social enterprises' efforts to combine commercial and social welfare logics. At the same time, these institutions might also constrain social enterprises' creativity, creating pressure to focus on particular business models or social missions. This phenomenon generates a number of questions for institutional research. In particular, what factors led to these changes in the institutional environment, and how do these changes in turn impact the continued creation and diffusion of social enterprises?

In addition, the cross-level nature of institutional theory offers opportunities to explore the relationship between individuals and societal institutions. Increasingly, scholars point to the role of individual agency in creating, maintaining, and disrupting institutions (Lawrence, Suddaby, \& Leca, 2011; Powell \& Colyvas, 2008). Much of the research on social enterprises stresses the roles and characteristics of these organizations' founders (Light, 2009; Zahra et al., 2009). From an institutional perspective, this research raises questions about the interaction between the individual and the environment. To what extent do social enterprises depend on specific types of leaders to effectively manage tensions? To what extent does the nature of the institutional environment influence leaders' ability to effectively attend to these tensions? Or, is there a structuration process by which individuals and institutions are co-created over time (Jarzabkowski, 2008)?

Finally, institutional research can continue to expand our understanding of the conditions under which particular tensions associated with competing logics become salient within social enterprises. We delineated varied competing demands that emerge in these organizations. Future research can offer insight into the institutions that make particular competing demands more or less salient for social entrepreneurs. For example, seeking legitimacy through multiple funding sources creates challenges for long-term scalability, leading to tensions of learning and growth, whereas societal-level institutions that train and reinforce distinct logics within individuals create challenges for hiring and socialization, giving rise to organizing tensions.

\section{Organizational Identity}

Organizational identity research offers insights into belonging tensions within social enterprises. Organizational identity refers to a perception shared by organizational members about "who we are" and "what we do" as an organization-the central and enduring characteristics that distinguish this particular organization from others (Albert \& Whetten, 1985). A clear and consistent organizational identity can guide, orient, and unify members of an organization to engage in collective action. Yet many organizations have hybrid identities which are "composed of two or more types that would not normally be expected to go together" (Albert \& Whetten, 1985: 270). Examples include research universities (Albert \& Whetten, 1985), cooperatives (Foreman \& Whetten, 2002), symphony orchestras (Glynn, 2000), hospitals (Pratt $\&$ Rafaeli, 1997), and, increasingly, social enterprises, which combine a normative 
identity arising from their social mission with a utilitarian identity arising from their business venture (Moss et al., 2011).

Organizational identity research suggests that enacting multiple identities simultaneously, as in hybrids, can lead to conflicts and controversy between competing internal groups (Glynn, 2000; Golden-Biddle \& Rao, 1997), precipitating or preventing strategic change and reorientations (Dutton \& Dukerich, 1991; Nag, Corley, \& Gioia, 2007) and threatening organizational performance (Voss, Cable, \& Voss, 2008). For example, Anteby and Wrzesniewski (Forthcoming) show how the multiple identities of Helping Hands, a French youth service organization, created confusion among members, challenging their identification with the organization. While the organization's hybrid identity of "helping others" and "helping oneself" attracted a diverse range of participants, members tended to focus on just one or the other of these identities. Some viewed themselves as future professionals in the social service sector and gravitated toward the "helping others" identity. Other members were "drifters" who sought to find a new direction in their own life and correspondingly emphasized the "helping oneself" identity. Interactions among these subgroups led to confusion about what Helping Hands really stood for and weakened members' ties to the organization. Such belonging tensions can ultimately impede organizational performance. In her study of a symphony orchestra, Glynn (2000) finds tensions between musicians, who valued the orchestra's artistic identity, and administrators, who valued its economic identity. When salary negotiations highlighted these differences, conflict became intractable, resulting in a musicians' strike and, later, the forced resignation of the music director.

Identity scholars offer varied perspectives on how organizations can address the belonging tensions that arise from conflicting identities. Some researchers highlight organization-level strategies for managing multiple identities, for example by deleting, compartmentalizing, aggregating, or integrating them (Pratt \& Foreman, 2000). Pratt and Corley (2007) build on this framework by considering how different identity management strategies create benefit or harm for individual members. Other researchers emphasize multi-level strategies. For example, organizations can encourage distinct identities among subgroups, while fostering a unified identity at the organizational level (Ashforth, Reingen, \& Ward, 2013; Fiol, Pratt, \& O'Connor, 2009). Similarly, Pratt and Kraatz (2009) suggest creating an "organizational self" to integrate multiple subgroup identities into a coherent whole. Scholars have also identified processes and practices that can mitigate conflicts arising from multiple identities. For example, Besharov (2013) describes practices that foster positive identification at "Natural Foods," a socially responsible retail company with both normative and utilitarian identities. She finds that by promoting members with commitments to both identities rather than to just one or the other, developing integrative solutions that address both social and commercial objectives, and embedding the social mission into required work procedures, Natural Foods overcame tensions between members who valued only the normative or only the utilitarian identity and enabled both types of members to experience a positive sense of belonging. Finally, some studies offer insight into how belonging tensions are managed by individual members. For example, research by Elsbach (2001) and Gutierrez and colleagues 
(Gutierrez, Howard-Grenville, \& Scully, 2010) illuminates the coping strategies adopted by individuals within multiple identity organizations, showing how members use "schizo" or "split" identification to maintain a positive self-identity and sense of belonging even as they dis-identify with particular attributes of their organization.

Future research from an organizational identity perspective can explore the nature and management of social enterprises' hybrid identities at multiple levels of analysis. At the individual level, studies can investigate which attributes of social enterprises' identities resonate with members and how members cope with identity attributes they do not value. Identity research on ambivalence and dis-identification may provide a useful starting point for this line of inquiry (Elsbach, 1999; Pratt, 2000). At the organizational level, empirical research could draw on Pratt and Foreman's (2000) typology of strategies for managing multiple identities to investigate the conditions under which social enterprises adopt these different approaches and the effectiveness of each one. Empirical studies are also needed to better understand the process through which social enterprises can create an integrated identity while simultaneously encouraging differentiated identities among subgroups associated with the social mission and business venture. In addition, identity research could provide insight into how the societal environment influences the formation and transformation of organizational identity, extending existing research that considers how outsiders' shifting perceptions of an organization influence insiders' sensemaking about the organization's identity (Dutton \& Dukerich, 1991).

Research from an identity perspective could also explore how social enterprises communicate their identities to relevant audiences. Identity can play a central role in establishing organizational legitimacy (see Navis \& Glynn, 2011), yet communicating a hybrid identity is particularly challenging. Research on social categorization has shown that organizations spanning multiple categories are less easily understood by audiences (Negro, Kocak, \& Hsu, 2010). For example, Zuckerman $(1999,2000)$ finds that firms that do not fit into a given business category receive less attention from analysts, which affects their share price. Similarly, Hsu (2006) notes that movies and films that span more genres are less attractive to audiences than those classified in an established genre. Social entrepreneurs recognize these challenges, describing the difficulty of positioning themselves with different external audiences (see Bell, 2011). Yet, while the liability linked with straddling multiple identity categories clearly applies to social enterprises, much more research is needed on how such organizations proactively manage this challenge and effectively communicate their hybrid identity to key audiences.

Finally, an organizational identity perspective can offer insight into the shifts and changes of social enterprises' identities over time. The tensions between normative and utilitarian identities create uncertainties and ambiguities, which can productively enable organizational identity to morph over time (Corley \& Gioia, 2004). How such identities change, what enables these changes, and how these changes impact the ability for the firm to sustain competing demands over time are all issues that offer fruitful avenues for future research. 


\section{Stakeholder Theory}

Stakeholder theory provides insight into performing tensions that emerge from addressing the demands of multiple stakeholders. In contrast to organizational theories that prioritize shareholder needs and emphasize profit maximization, a stakeholder perspective recognizes that organizations operate within and are accountable to a broad ecosystem, a shift of perspective which surfaces ethical and societal issues (Donaldson \& Preston, 1995; Freeman, 1984). Addressing multiple stakeholders raises questions about "who and what really counts" (Freeman, 1984) - that is, who to include as stakeholders and which claims to address. Stakeholder research offers three approaches to answering these questions-descriptive, instrumental, and normative (Donaldson \& Preston, 1995).

Descriptive studies point to the broad range of organizations that already embed multiple stakeholder needs in their strategic decision making (Frooman, 1999; Rowley \& Moldoveanu, 2003; Wang \& Dewhirst, 1992). Instrumental studies emphasize the economic impact of addressing moral and ethical concerns, examining how a stakeholder (vs. a shareholder) approach affects a firm's financial performance (Agle, Mitchell, \& Sonnenfeld, 1999; Berman, Wicks, Kotha, \& Jones, 1999; Ogden \& Watson, 1999). Instrumental studies suggest that, at a minimum, a stakeholder approach does no worse to a firm's financial outcomes than a shareholder approach (Mitchell, Agle, \& Wood, 1997). As a result, instrumental studies reinforce Donaldson and Preston's (1995) assertion that the "fundamental basis" of stakeholder theory is a normative approach, which articulates moral reasons for addressing multiple stakeholders. Normative criteria include issues of fairness (Driver, 2012; Pache \& Chowdhury, 2012), legitimacy (Driver, 2012; Miller, Wesley, \& Williams, 2012; Tracey, 2012), and reciprocity (Phillips \& Freeman, 2008). Some normative stakeholder theorists also point to broader community perceptions as a basis for deciding which stakeholder claims to address. For example, Baur and Palazzo (2011) emphasize that legitimacy depends on the stakeholder's discourse and engagement in broader communities. Integrating both instrumental and normative approaches, Mitchell, Agle, and Wood (1997) propose a model for identifying and evaluating the salience of stakeholder claims based on urgency, power, and legitimacy. Urgency describes the claims' time-sensitivity and critical importance for the stakeholder; power refers to the stakeholder's ability to force another actor to do something; and legitimacy is "a generalized perception or assumption that the actions of an entity are desirable, proper, or appropriate within some socially constructed system of norms, values, beliefs, and definitions" (Suchman, 1995: 574).

By definition, social enterprises embrace multiple stakeholders in their pursuit of social missions through business ventures. As we noted earlier, this raises critical tensions. To date, much of the research on the tensions between stakeholders in social enterprises adopts a descriptive approach, pointing to salient exemplars (Chowdhury \& Santos, 2011; Mair \& Martí, 2009) or emphasizing flourishing numbers of organizations and supporting institutions (Boyd, Henning, Reyna, Wang, \& Welch, 2009; Hoffman et al., 2010). For example, extensive social enterprise research draws on case analyses of organizations that successfully address multiple 
stakeholder demands. In a recent interview, Mohammed Yunus, founder of Grameen Bank, invoked descriptive arguments when he pointed to the success of microcredit as a means of effectively responding to both social and business demands within the same organization (Bornstein, 2013). Descriptive approaches further emphasize the number of stakeholders that can be involved in social enterprises. Kania and Kramer (2011) note that successful system-wide initiatives often depend on a broad range of stakeholders. For instance, the Elizabeth River Project in Virginia brought together over 100 stakeholders to address the pollution issues. Similarly, the Grameen group has been able to expand its offerings and develop products such as yogurt with high nutritional value, mosquito nets, and mobile telephone services through collaboration with multiple, diverse partners including Danone, BASF, and Telenor (Yunus, 2010).

Social enterprise research further adopts instrumental and normative arguments to address tensions between stakeholder demands. Instrumental justifications, for example, inform Haigh and Hoffman's (2012) discussion of hybrid organizations pursuing social missions and commercial ventures. Their arguments suggest that the success of social enterprises comes in part from the mutually beneficial relationships forged between multiple stakeholders. These organizations emphasize community integration and display trust, compassion, and cooperation with broad groups of stakeholders, creating positive benefits across all stakeholders. In other research, Cooney (2012) adopts Mitchell, Agle, and Wood's (1997) criteria of urgency, power, and legitimacy to evaluate the role of multiple stakeholders in various new legal forms for social enterprises. She finds that these forms vary in the degree to which they afford salience to multiple stakeholders based on these criteria.

A stakeholder perspective also suggests several avenues for future research on tensions in social enterprises. From a normative perspective, criteria around power, legitimacy, and urgency can help social enterprises evaluate the moral importance of claims made by a large and diverse group of stakeholders (Kania \& Kramer, 2011). Stakeholder theory could be used to evaluate the legitimacy of social enterprises themselves as stakeholders of the communities they aim to serve, especially when they seek to change cultural values. For example, Gram Vikas challenges the long established caste system in India, seeking to replace these cultural hierarchies with more egalitarian values (Chowdhury \& Santos, 2011). To be seen as legitimate, such changes require normative support, and stakeholder theorists suggest such support can be gained through proactive interactions with other actors in civil society (Baur $\&$ Palazzo, 2011). Understanding how this process works for social enterprises is an important topic for future research. Moreover, some scholars argue that attaining legitimacy for societal and cultural changes requires democratic structures that involve multiple stakeholders (Defourny \& Nyssens, 2010; Hart, Laville, \& Cattani, 2010). To the extent that participatory democracy is seen as required, this raises additional questions about the criteria and processes for establishing legitimate community interventions, including issues about the appropriate legal form of social enterprises. Finally, a stakeholder approach can help explore in more depth questions about potentially unethical relations with key stakeholders such as beneficiaries. In particular, how might social enterprises, in the name of their social mission, abuse 
their power and work against some stakeholders in order to protect either their own interests or those of other stakeholders?

\section{Paradox Theory}

Paradox theory can extend our understanding of the nature and management of multiple types of tensions within social enterprises. Paradoxes refer to "contradictory, yet interrelated elements-elements that seem logical in isolation, but absurd and irrational when appearing simultaneously" (Lewis, 2000: 760). Philosophers have long reflected on logical or rhetorical paradoxes, exemplified in the self-referential statement, "I am lying." More recently, organizational scholars have expanded upon the paradoxical nature of social life, noting the simultaneity of contradictory elements within social systems (Quinn \& Cameron, 1988; Smith \& Berg, 1987). Unlike logic or rhetoric, social paradoxes depend on how actors frame temporal and spatial boundaries (Argyris, 1988; Bartunek, 1988). Contradictory elements can seem like a dilemma that can be separated by time or space (Poole \& Van de Ven, 1989). However, similar to logical or rhetorical paradox, in social paradoxes contradictory elements continue to exist simultaneously and persist over time (Smith \& Lewis, 2011). As Smith and Lewis note, "A dilemma may prove paradoxical, for instance, when a longer time horizon shows how any choice between A and B is temporary. Over time the contradictions resurface, suggesting their interrelatedness and persistence" (Smith \& Lewis, 2011: 387). Efforts to split paradoxical tensions and choose one alternative only intensify the other and fuel vicious cycles between them (Smith \& Berg, 1987; Sundaramurthy \& Lewis, 2003). In contrast, engaging paradoxical tensions simultaneously can generate novel, creative ideas (Eisenhardt \& Westcott, 1988; Rothenberg, 1979) and enable long term organizational success and sustainability (Cameron, 1986; Cameron \& Lavine, 2006; Smith, Lewis, \& Tushman, 2011). Exploration and exploitation offer one example. In the short term, organizational leaders can approach the tension between exploring new opportunities and exploiting existing certainties as a dilemma, choosing where to allocate resources. Yet over time, exploiting existing certainties depends on having explored new possibilities and vice versa (Smith \& Tushman, 2005).

Paradoxes offer an "invitation to act" in novel ways that engage and accept complexities and contradictions (Beech, Burns, de Caestecker, MacIntosh, \& MacLean, 2004). Scholars elaborate different approaches to doing this, including temporally separating and shifting between alternatives, spatially separating alternatives within different organizational boundaries, and finding ways to address competing alternatives simultaneously (Lewis, 2000; Poole \& Van de Ven, 1989). Smith and Lewis (2011) suggest that embracing paradoxical tensions depends on a combination of these strategies, involving forces that accommodate competing demands simultaneously, while creating opportunities to emphasize distinct needs. This requires both differentiating between and integrating across paradoxical tensions (Andriopoulos \& Lewis, 2009; Smith, 2013; Smith \& Tushman, 2005). Other research focuses on individual and organizational capabilities for managing paradoxes. For example, one stream of work emphasizes cognition, stressing mental frames that embrace and 
engage competing demands simultaneously, rather than split or choose between alternatives (Bartunek, 1988; Eisenhardt \& Westcott, 1988). This can be accomplished through paradoxical (Smith \& Tushman, 2005) or integrative thinking (Martin, 2007), which juxtaposes tensions and provokes a search for novel ideas. Another stream of research emphasizes the role of organizational practices and routines to support contradictory demands. For example, Luscher and Lewis (2008) posit that inquiry practices shift the focus from dilemmas to paradoxes, eliciting "workable certainties" that enable organizations to move forward.

Paradox theory complicates our understanding of the relationship between social missions and business ventures in social enterprises. This lens not only recognizes that their combination raises contradictory demands, it also explores how these demands are interrelated and mutually constitutive. Social missions and business ventures can reinforce one another, such that long-term success depends on attending to both. For example, two meta-analyses suggest that in the long-term, a company's social performance and financial performance enable one another (Margolis \& Walsh, 2003; Orlitzky, Schmidt, \& Rynes, 2003). In social enterprises, the relationship between social missions and economic outcomes is not only mutually beneficial, but also mutually constitutive, such that social missions define business purposes and vice versa. At Digital Divide Data, for example, pursuing commercial success reinforces the organization's social mission, as having clients who demand high quality work intensifies the pressures and opportunities for operators to learn quickly and build skills, while also providing professional experience that can help operators attain better jobs in the future. Moreover, the revenues earned from clients contribute to the social mission, by enabling Digital Divide Data to provide operators with increased salaries, helping them to break out of poverty and improve the lives of their parents and siblings as well. At the same time, the organization's social mission contributes to its commercial success, by serving as a marketing tool with clients in a particularly competitive industry.

Scholars increasingly recognize the paradoxical and mutually constitutive relationship between social missions and business ventures within social enterprises. For example, Smith, Besharov, Wessels, and Chertok (2012) explore how these paradoxical tensions impact strategic decision making, as leaders strive to attend to both social missions and business ventures, while needing to make decisions between them. Jay (2013) notes the performance paradox that surfaces in social enterprises when the metrics for social mission success imply failure for the business venture and vice versa. Other scholars focus how paradoxes manifest in role conflict within social enterprises. For example, board members experience tensions between their autocratic and democratic roles. They need to be autocratic in order to enable more collaboration, connection, and democratic relationships, yet they also need to engage democratic processes in order to autocratically influence their organization (Cornforth, 2004). These tensions become particularly salient in employee-owned organizations, where employees require direction and control to enable them to effectively be directive and participatory (Stoltzfus, Stohl, \& Seibold, 2011; Westenholz, 1993). 
In addition to showing how paradoxical tensions manifest, research adopting this lens offers insight into strategies for managing these tensions. Smith, Besharov, Wessels, and Chertok (2012) suggest managing paradoxical tensions requires leaders who have capabilities for accepting paradoxes, differentiating between competing demands, and simultaneously integrating across these demands. Other studies emphasize the importance of emotional complexity for managing defensiveness and anxiety, interpersonal interactions for ensuring effective communication and minimizing conflict (Lewis, Andriopoulos, \& Smith, Forthcoming), and cognitive complexity for fostering integrative thinking (Martin, 2007; Tracey et al., 2011). Jay's (2013) study of the Cambridge Energy Alliance describes how sensemaking enables dynamic definitions of success in the context of performance paradoxes.

These studies set the foundation for further social enterprise research that adopts a paradox lens. While many studies describe the contradictions and tensions between social missions and business ventures, existing research offers less insight into the mutually constitutive nature of social missions and business ventures. That is, beyond just benefitting one another, how do these demands define one another (Farjoun, 2010; Feldman \& Orlikowski, 2011; Sundaramurthy \& Lewis, 2003)? Understanding this relationship in more depth can provide insight into how to engage and manage paradoxical tensions. Future research can also expand our understanding of the characteristics of leaders who are able to manage paradoxical tensions in social enterprises, building on the studies described above that explore individual capabilities associated with effective management of paradox. For example, research suggests that adopting an abundance mentality in the face of seemingly scarce resources shifts leaders' mental models from competition to cooperation, enabling them to more fully embrace paradoxical tensions (Cameron \& Lavine, 2006; Smith, 2002). In addition, the emotional capability to manage anxiety or defensiveness reduces resistance to paradoxical demands and invites the possibility for uncertainty to lead to beneficial outcomes (Lewis et al., 2013; Vince \& Broussine, 1996). Future research could explore additional capabilities that enable social entrepreneurs to effectively respond to the competing demands that arise from social missions and business ventures.

Finally, research could explore in more depth the organizational structures associated with managing competing demands. As we noted, scholars have identified different approaches to attending to competing demands, including creating temporal or spatial separation and seeking synergies through integration of competing demands. Examples of each approach can be found among social enterprises. Some organizations alternate their focus over time between social concerns and business purposes, illustrating temporal separation (Jay, 2013), while others create distinct boundaries between their business ventures and social missions, illustrating spatial separation (Battilana et al., 2012). Still other social enterprises have developed novel structures that integrate social missions with business ventures (Smith et al., 2007). Future research can explore the nature of each of these structures, the conditions under which each structure might emerge, and the factors that enable each to be successful. For example, Weaver, Treviño, and Cochran (1999) consider how conditions such as managerial commitments, external pressures, and specific 
practices lead to different approaches to integrating ethics in corporate organizations. Investigating how these factors impact the structure of social enterprises may be a fruitful avenue for future research.

\section{DISCUSSION}

Social enterprises continue to grow in number and influence to address world problems of poverty, environmental degradation, and moral injustice. Effectively understanding these hybrid organizations depends on recognizing the tensions that emerge from their commitments to both social missions and business ventures. Seeking to expand insight into social enterprises, we categorized tensions within social enterprises based on Smith and Lewis's (2011) typology and then identified existing insights and future research questions about these tensions. Following others (Dacin et al., 2011; Dacin et al., 2010), we considered what can be learned from existing theories, adopting four theoretical lenses that are particularly relevant for understanding the distinctions, as well as interactions, between social missions and business ventures. Taken together, our review and analysis offers a research agenda for understanding social-business tensions within social enterprises. Yet even as existing organizational theories provide insight into this issue, focusing on tensions within social enterprises also offers a fruitful avenue for understanding how, in turn, research on social enterprise can inform existing theories. In this section, we elaborate on this possibility by considering how social enterprises can serve as a setting for studying the nature and management of tensions in organizations more generally and therefore, how research on tensions within social enterprises can contribute to existing organizational theories.

\section{Contributions of Social Enterprise Research to Organizational Theory}

Historically, scholars acknowledged that organizations embed contradictory demands from divergent internal subgroups (Cyert \& March, 1963) and external stakeholders (Selznick, 1957), but suggested that success depended on choosing between these demands (Thompson, 1967) to minimize ambiguity for internal constituents (Jensen, 2008) and gain legitimacy with external constituents (DiMaggio \& Powell, 1983). External education, training, and cultural institutions reinforce the specialization of organizations, suggesting that hybrids have little opportunity to emerge and survive (Gonin, 2007). Yet scholars from varied theoretical perspectives now recognize the frequency and salience of competing demands. Institutional theorists emphasize conditions of institutional plurality and complexity, or the competing institutional pressures that emerge from the societal environment (Greenwood, Díaz, Li, \& Lorente, 2010; Kraatz \& Block, 2008; Pache \& Santos, 2010). Organizational identity research highlights the prevalence of multiple organizational identities (Albert \& Whetten, 1985; Pratt \& Foreman, 2000). Stakeholder theory explores whether and when organizations attend to multiple, often competing demands from a broad network of stakeholders (Agle, Donaldson, Freeman, Jensen, Mitchell, \& Wood, 2008), while paradox theory argues that competing demands are inherent in organizations and emerge through the act of organizing (Ford \& Backoff, 1988). 
Competing demands emerge across varied types of organizations. For example, a broad range of organizations beyond social enterprises experience tensions between social missions and business ventures, including employee- or customer-owned organizations (Stohl \& Cheney, 2001), traditional not-for-profits that face intensified financial pressures (Mersland \& Strom, 2010), as well as traditional for-profits that face increased demands for social responsibility (Margolis \& Walsh, 2003). Moreover, beyond social-business tensions, organizations face many other types of competing demands. The global, hypercompetitive, and fast-paced nature of our environment surfaces tensions between exploration and exploitation (March, 1991; Smith \& Tushman, 2005), stability and change (Farjoun, 2010), and global demands and local needs (Marquis \& Battilana, 2009). Similar to the relationship between social missions and business ventures, these tensions represent commitments at the organizational level to strategies with divergent goals, logics, values, norms, and identities.

Social enterprises provide evidence of the potential to thrive and survive as hybrid organizations attending to competing demands. Whereas social enterprises were once prevalent primarily in the education and health care sectors, these organizations now populate financial services, agriculture, information technology, and retail industries as well (Battilana \& Dorado, 2010; Haigh \& Hoffman, 2012; Seelos \& Mair, 2005). Moreover, as these organizations multiply, so too do institutional actors that support their hybrid status, including investors, philanthropies, educational institutions, and research organizations. Social enterprises have succeeded not only in surviving and expanding, but also in developing novel approaches to some of the world's greatest problems. In this respect they exemplify the benefits that can emerge from juxtaposing seemingly contradictory or inconsistent demands simultaneously (Seo \& Creed, 2002; Smith \& Lewis, 2011).

Succeeding as a social enterprise is challenging, however. Our review highlighted a number of issues that emerge from the social-business tensions embedded within social enterprises. Attending to both social missions and business ventures creates problems for gaining legitimacy with stakeholders, sustaining commitments to both social and commercial goals over time, and managing internal relations among members. We described above how institutional, identity, stakeholder, and paradox lenses offer insights into the nature of these tensions and managerial responses. Here we suggest several ways in which these insights can contribute to organizational theories about competing demands in organizations more broadly.

First, from an institutional perspective, understanding tensions within social enterprises can inform research on the environmental and organizational factors that impact the survival and effectiveness of hybrid organizations (Besharov \& Smith, 2013; Pache \& Santos, 2010). Social enterprises can also provide a setting for exploring the evolution of institutions and the long-term viability of organizations that are located at the interstices of existing institutional fields.

Second, social enterprise research can expand theory in organizational identity by enriching our understanding of the nature and management of multiple identities within organizations (Pratt \& Foreman, 2000). Research on social enterprises can also inform our understanding of how multiple and hybrid identity organizations 
overcome the tendency toward conflict and dis-identification among members and instead foster positive identification (Besharov, 2013).

Third, stakeholder theory can benefit from research on how social enterprises manage their numerous stakeholders. Funders, philanthropies, customers, and employees can fundamentally disagree with one another, yet they are all important for the success of a social enterprise (Grimes, 2010). Scholars are starting to offer strategies for how social enterprises can accommodate these divergent interests. For example, Kania and Kramer (2011) identify types of collaborations and conditions for success, including the development of a common agenda, shared measurement systems, mutually reinforcing activities, continuous communication, and backbone support organizations. This work can enrich stakeholder theory by addressing calls to not only recognize the "right" stakeholders, but also to develop strategies for managing these stakeholders effectively (Argenti, 2004; Berger, Cunningham, \& Drumwright, 2004; Swartz, 2010). In addition, research on social enterprises that employ participatory governance can shed new light on the descriptive-normative debate within stakeholder research (Treviño \& Weaver, 1999), as these organizations might have developed explicit tools and routines for identifying and including normatively important stakeholders (Defourny \& Nyssens, 2010; Forcadell, 2005).

Finally, social enterprise research can inform paradox theory by providing a setting that makes salient the tensions between social missions and business purposes. As Smith and Lewis (2011) note, these kinds of tensions may exist in broad types of firms, but they become particularly salient under conditions of scarcity, plurality, and change. Social enterprises emphasize plurality, or the commitment to multiple demands. Moreover, in social enterprises, these tensions are permanent and pervasive aspects of the organization. Understanding how these tensions manifest as paradoxes, and how leaders embrace and benefit from these tensions in social enterprises, can provide insight into managing paradoxical tensions in other organizations. In summary, a research agenda around social-business tensions within social enterprises not only offers the promise of a better understanding this phenomenon, but it can also contribute to, challenge, and extend mainstream organizational theories.

\section{Future Research: Multiple Tensions and Theoretical Perspectives}

While social enterprises may offer insights into the nature and management of organizational tensions more generally, further research can explore how tensions within social enterprises may differ from those in other organizations. Like corporations grappling with social responsibility, social enterprises juxtapose social and ethical demands against economic concerns. However, corporations face different pressures than social enterprises in how to manage these demands, including pressure for short-term financial success that emerges from investors and markets. Scholars have begun to explore how the nature and environment of these competing demands differ and may lead to alternative management strategies. For example, Pache and Santos (2010) argue that competing demands become more salient for organizations when they operate in fragmented and moderately centralized fields. They further suggest that organizational responses to demands will vary depend- 
ing on whether the demands are associated with goals or means, and on how the demands are represented internally. Pratt and Foreman (2000) argue that managerial responses to competing demands that arise from multiple identities depend on the number of identities and the synergy between them. Future research is needed to empirically explore differences in the nature of competing demands and in the environments in which they surface, as well as the implications these differences have for managerial responses.

Such studies can offer important insights for business and society research, as concepts from the latter are closely related to the nature of social enterprise. Citizenship, for example, is linked to community interest companies, an emergent legal form for social enterprises (Haugh \& Peredo, 2010; Moon, Crane, \& Matten, 2005), and Aristotelian virtue is not unfamiliar to social entrepreneurs pursuing the common good (Bornstein, 2004; Sisón, Hartman, \& Fontrodona, 2012). Given these connections, a better understanding of social enterprises' expertise in managing tensions and transforming them into potential drivers of innovation and entrepreneurship can offer insights into how traditional businesses can better manage their social responsibilities. For such cross-fertilization between social enterprise and business-society research to be fruitful, however, the core difference between the types of organizations on which each literature focuses-namely the dominance of social mission in the former case and of profit in the latter case-needs to be more thoroughly addressed. To the extent that social enterprises do not face the same pressure for profit maximization as publicly-traded companies, they have more freedom to engage in social and environmental initiatives even if these activities are not profitable. Yet, as market actors, social enterprises must still ensure that their social involvement does not lead to bankruptcy, and so they also face strong economic constraints.

Future research is also needed to develop connections and linkages among the different theoretical lenses we explored. For example, the juxtaposition of conflicting institutional logics raises paradoxical tensions and creates challenges for stakeholder management as organizations face stakeholders tied to divergent logics. In addition, an organization's identity depends in part on the institutional context within which it operates and on its relations with particular types of stakeholders. Our review surfaces these interconnections in the context of social enterprise, and it thereby points to the need for more integrative frameworks that bring together into a coherent whole the perspectives offered by each individual lens.

Finally, our analysis focused on four theoretical lenses for understanding tensions within social enterprises. These lenses offer complementary insights from multiple levels of analysis. Institutional theory and stakeholder theory emphasize the role of environment, context, and external stakeholders in creating and supporting tensions within social enterprises, while organizational identity and paradox theory focus on how tensions arise from internal organizational dynamics. Each of these lenses reinforces the distinctions between social missions and business ventures, while also proffering possibilities for synergies. While these lenses offer rich insights and possibilities for additional research, future work should also consider how other theoretical approaches can contribute to our understanding of tensions within social 
enterprises. For example, network theory can offer insight into the diffusion of strategies for managing competing demands (Davis, 1991; Galaskiewicz \& Burt, 1991) and how network ties contribute to social enterprises' ability to effectively manage these demands (Galaskiewicz, Bielefeld, \& Dowell, 2006; Stuart, Hoang, \& Hybels, 1999). Sensemaking theory can provide additional insight into how leaders conceive of the relationship between competing demands (Jay, 2013; Sonenshein, 2006).

\section{CONCLUSION}

Over ten years ago, Margolis and Walsh (2003) urged organizational scholars to explore the "antinomies" that exist between social missions and business ventures. This line of inquiry, they argued, would offer important insights into the challenges and opportunities for businesses pursuing a social agenda. Their purpose was simple. They reviewed the literature on social performance in businesses and found academics to mostly be concerned with whether businesses benefited from attending to social missions. Scholars sought to make a "business case" for social responsibility, offering utilitarian or instrumental justification. Yet as Margolis and Walsh (2003) noted, this focus on justifying social responsibility was curious, in part because so many organizations already adopted social missions, irrespective of the business case. Leaders of such organizations were more interested in understanding how to do so effectively, than in whether or not to do so at all. Margolis and Walsh argued for the value of beginning this inquiry with the antinomies, or tensions, between social missions and business ventures.

Over ten years later, we make a similar plea. Social enterprise research is growing along with the expansion of these organizations. Insights from this research stream echo ideas from Margolis and Walsh (2003): pursuing social missions through business ventures raises inherent tensions and competing demands, and addressing these tensions is critical to understanding social enterprises. We reassert their call to take seriously social-business tensions and to embed them in our inquiry into social enterprises going forward. Doing so may offer important insights not only into this growing phenomenon; it may also expand our thinking within organization and management theory more broadly.

\section{NOTES}

We wish to thank Nicolas Gachet for his contributions to earlier versions of this manuscript. We further appreciate the guidance of the reviewers and editors at BEQ.

1. All authors contributed equally to this manuscript.

\section{REFERENCES}

Agle, B. R., Donaldson, T., Freeman, R. E., Jensen, M. C., Mitchell, R. K., \& Wood, D. J. 2008. Dialogue: Toward superior stakeholder theory. Business Ethics Quarterly, 18(2): 153-90. http://dx.doi.org/10.5840/beq200818214 
Agle, B. R., Mitchell, R. K., \& Sonnenfeld, J. A. 1999. Who matters to CEOs? An investigation of stakeholder attributes and salience, corporate performance, and CEO values. Academy of Management Journal, 42(5): 507-25. http://dx.doi.org/10.2307/256973

Albert, S., \& Whetten, D. A. 1985. Organizational identity. Research in Organizational Behavior, 7: 263-95.

Alter, S. K. 2008. Social enterprise models and their mission and money relationship. In A. Nicholls (Ed.), Social entrepreneurship: New models of sustainable social change: 205-32. Oxford: Oxford University Press.

Andriopoulos, C., \& Lewis, M. W. 2009. Exploitation-exploration tensions and organizational ambidexterity: Managing paradoxes of innovation. Organization Science, 20(4): 696-717. http://dx.doi.org/10.1287/orsc.1080.0406

Anteby, M., \& Wrzesniewski, A. Forthcoming. In search of the self at work: Young adults' experiences of a dual identity organization. Research in the Sociology of Work.

Argenti, P. A. 2004. Collaborating with activists: How Starbucks works with NGOs. California Management Review, 47(1): 91-116. http://dx.doi.org/10.2307/41166288

Argyris, C. 1988. Crafting a theory of practice: The case of organizational paradoxes. In R. Quinn \& K. Cameron (Eds.), Paradox and transformation: Toward a theory of change in organization and management: 255-78. Cambridge, MA: Ballinger.

Ashforth, B. E., Reingen, P. H., \& Ward, J. C. 2013. Friend and foe? The dynamics of an organizational duality in a natural food cooperative. Administrative Science Quarterly, Provisional Accept.

Bartunek, J. 1988. The dynamics of personal and organizational reframing. In R. Quinn \& K. Cameron (Eds.), Paradox and transformation: Toward a theory of change in organization and management: 137-62. Cambridge, MA: Ballinger.

Battilana, J., \& Dorado, S. 2010. Building sustainable hybrid organizations: The case of commercial microfinance organizations. Academy of Management Journal, 53(6): 1419-40. http://dx.doi.org/10.5465/AMJ.2010.57318391

Battilana, J., Lee, M., Walker, J., \& Dorsey, C. 2012. In search of the hybrid ideal. Stanford Social Innovation Review, 10(3) (Summer): 51-55.

Battilana, J., Pache, A. C., Sengul, M., \& Model, J. 2011. Beyond organizational instability and conflict: On the challenges of remaining hybrid. Working Paper, Harvard University, Cambridge, MA.

2013. Keeping a foot in both camps: Understanding the drivers of social performance in hybrid organizations. Working Paper, Harvard University, Cambridge, MA.

Baur, D., \& Palazzo, G. 2011. The moral legitimacy of NGOs as partners of corporations. Business Ethics Quarterly, 21(4): 579-604. http://dx.doi.org/10.5840/beq201121437

Beech, N., Burns, H., de Caestecker, L., MacIntosh, R., \& MacLean, D. 2004. Paradox as invitation to act in problematic change situations. Human Relations, 57(10): 1313-1332. http://dx.doi.org/10.1177/0018726704048357

Bell, T. 2011. Being the only b. Stanford Social Innovation Review, 9(3): 27-28. 
Berger, I. E., Cunningham, P. H., \& Drumwright, M. E. 2004. Social alliances: Company/ nonprofit collaboration. California Management Review, 47: 58-90. http://dx.doi.org/10.2307/41166287

Berman, S. L., Wicks, A. C., Kotha, S., \& Jones, T. M. 1999. Does stakeholder orientation matter? The relationship between stakeholder management models and firm financial performance. Academy of Management Journal, 42(5): 488-506. http://dx.doi.org/10.2307/256972

Besharov, M. L. 2013. Toward a relational ecology of identification: A process model of managing identification based on divergent values. Working paper, Cornell University, Ithaca, NY.

Besharov, M. L., \& Smith, W. K. 2013. Multiple logics within organizations: An integrative framework and model of organizational hybridity. Working paper, Cornell University, Ithaca, NY.

Bornstein, D. 2004. How to change the world: Social entrepreneurs and the power of new ideas. Oxford: Oxford University Press. 2013. Beyond profit: A talk with Muhammad Yunus. New York Times (April 17).

Borzaga, C., \& Santuari, A. 2001. Italy: From traditional co-operatives to innovative social enterprises. In C. Borzaga \& J. Defourny (Eds.), The emergence of social enterprise: 166-81. London: Routledge.

Boyd, B., Henning, N., Reyna, E., Wang, D., \& Welch, M. 2009. Hybrid organizations: New business models for environmental leadership. Sheffield, UK: Greenleaf.

Bromberger, A. R. 2011. A new type of hybrid. Stanford Social Innovation Review, 9(2): 49-53.

Cameron, K. 1986. Effectiveness as paradox: Consensus and conflict in conceptions of organizational effectiveness. Management Science, 32(5): 539-53. http://dx.doi.org/10.1287/mnsc.32.5.539

Cameron, K., \& Lavine, M. 2006. Making the impossible possible: Leading extraordinary performance. San Francisco: Berrett-Koehler.

Chowdhury, I., \& Santos, F. M. 2011. Gram vikas. In J. Hamschmidt \& M. Pirson (Eds.), Case studies in social entrepreneurship and sustainability: 43-68. Sheffield, UK: Greenleaf Publishing.

Cooney, K. 2012. Mission control: Examining the institutionalization of new legal forms of social enterprise in different strategic action fields. In B. Gidron \& Y. Hasenfeld (Eds.), Social enterprises: An organizational perspective. New York: Palgrave Macmillan.

Corley, K. G., \& Gioia, D. A. 2004. Identity ambiguity and change in the wake of a corporate spin-off. Administrative Science Quarterly, 49(2): 173-208.

Cornforth, C. 2004. The governance of cooperatives and mutual associations: A paradox perspective. Annals of Public and Cooperative Economics, 71: 11-32. http://dx.doi.org/10.1111/j.1467-8292.2004.00241.x

Cyert, R. M., \& March, J. G. 1963. A behavioral theory of the firm. Englewood Cliffs, NJ: Prentice Hall. 
Dacin, M. T., Dacin, P. A., \& Tracey, P. 2011. Social entrepreneurship: A critique and future directions. Organization Science, 22(5): 1203-13.

http://dx.doi.org/10.1287/orsc.1100.0620

Dacin, P. A., Dacin, M. T., \& Matear, M. 2010. Social entrepreneurship: Why we don't need a new theory and how we move forward from here. Academy of Management Perspectives, 24(3): 37-57. http://dx.doi.org/10.5465/AMP.2010.52842950

Davis, G. F. 1991. Agents without principles? The spread of the poison pill through the intercorporate network. Administrative Science Quarterly, 36(4): 583-613. http://dx.doi.org/10.2307/2393275

Dees, J. G. 2001. The meaning of social entrepreneurship. http://www.caseatduke.org, Original draft: 1998, Revised 2001.

2007. Taking social entrepreneurship seriously: Uncertainty, innovation, and social problem solving. Society, 44(3): 24-31.

http://dx.doi.org/10.1007/BF02819936

2012. A tale of two cultures: Charity, problem solving, and the future of social entrepreneurship. Journal of Business Ethics, 111(3): 321-34.

http://dx.doi.org/10.1007/s10551-012-1412-5

Dees, J. G., Battle Anderson, B., \& Wei-Skillern, J. 2004. Scaling social enterpreneurship: Strategies for spreading social innovations. Stanford Social Innovation Review, 1(4): 24-32.

Defourny, J., \& Nyssens, M. 2010. Conceptions of social enterprise and social entrepreneurship in Europe and the United States: Convergences and divergences. Journal of Social Entrepreneurship, 1(1): 32-53. http://dx.doi.org/10.1080/19420670903442053

Denis, J.-1., Langley, A., \& Rouleau, L. 2006. The power of numbers in strategizing. Strategic Organization, 4(4): 349-77. http://dx.doi.org/10.1177/1476127006069427

DiMaggio, P. 1988. Interest and agency in institutional theory. In L. G. Zucker (Ed.), Institutional patterns and organizations: 3-21. Cambridge, MA: Ballinger.

DiMaggio, P., \& Powell, W. W. 1983. The iron cage revisited: Institutional isomorphism and collective rationality in organizational fields. American Sociological Review, 48(2): 147-60. http://dx.doi.org/10.2307/2095101

Donaldson, T., \& Preston, L. E. 1995. The stakeholder theory of the corporation: Concepts, evidence, and implications. Academy of Management Review, 20(1): 65-91.

Driver, M. 2012. An interview with Michael Porter: Social entrepreneurship and the transformation of capitalism. Academy of Management Learning \& Education, 11(3): 421-31.

Dutton, J., \& Dukerich, J. 1991. Keeping an eye on the mirror: Image and identity in organizational adaptation. Academy of Management Journal, 34(3): 517-54. http://dx.doi.org/10.2307/256405

Ebrahim, A., \& Rangan, V. K. 2010. Putting the brakes on impact: A contingency framework for measuring social impact. Academy of Management Proceedings.

Eisenhardt, K. M., \& Westcott, B. 1988. Paradoxical demands and the creation of excellence: The case of just in time manufacturing. In R. Quinn \& K. Cameron (Eds.), Paradox and transformation: Toward a theory of change in organization and management: 19-54. Cambridge, MA: Ballinger. 
Elsbach, K. 1999. An expanded model of organizational identification. In R. I. Sutton \& B. M. Staw (Eds.), Research in organizational behavior, vol. 21: 163-99. Greenwich, CT: JAI Press.

2001. Coping with hybrid organizational identities: Evidence from California legislative staff. In J. Wagner (Ed.), Advances in qualitative organizational research, vol. 3: 59-90. Oxford: Elsevier Science Ltd.

Epstein, M. 2008. Making sustainability work. Sheffield, UK: Greenleaf Publishing.

Farjoun, M. 2010. Beyond dualism: Stability and change as duality. Academy of Management Review, 35(2): 202-25. http://dx.doi.org/10.5465/AMR.2010.48463331

Feldman, M. S., \& Orlikowski, W. J. 2011. Theorizing practice and practicing theory. Organization Science, 22: 1240-53. http://dx.doi.org/10.1287/orsc.1100.0612

Fiol, C. M., Pratt, M. G., \& O’Connor, E. J. 2009. Managing intractable identity conflict. Academy of Management Review, 34(1): 32-55. http://dx.doi.org/10.5465/AMR.2009.35713276

Forcadell, F. 2005. Democracy, cooperation and business success: The case of Mondragón Corporación Cooperativa. Journal of Business Ethics, 56(3): 255-74. http://dx.doi.org/10.1007/s10551-004-5094-5

Ford, J., \& Backoff, R. 1988. Organizational change in and out of dualities and paradox. In R. Quinn \& K. Cameron (Eds.), Paradox and transformation: Toward a theory of change in organization and management: 81-121. Cambridge, MA: Ballinger.

Foreman, P. O., \& Whetten, D. A. 2002. Members' identification with multiple-identity organizations. Organization Science, 13(6): 618-35.

http://dx.doi.org/10.1287/orsc.13.6.618.493

Freeman, R. E. 1984. Strategic management: A stakeholder approach. Boston: Pitman.

Frooman, J. 1999. Stakeholder influence strategies. Academy of Management Review, 24(2): 191-205.

Galaskiewicz, J., Bielefeld, W., \& Dowell, M. 2006. Networks and organizational growth: A study of community based nonprofits. Administrative Science Quarterly, 51(3): 337-80.

Galaskiewicz, J., \& Burt, R. S. 1991. Interorganization contagion in corporate philanthropy. Administrative Science Quarterly, 36(1): 88-105. http://dx.doi.org/10.2307/2393431

Glynn, M. A. 2000. When cymbals become symbols: Conflict over organizational identity within a symphony orchestra. Organization Science, 11(3): 285-98. http://dx.doi.org/10.1287/orsc.11.3.285.12496

Golden-Biddle, K., \& Rao, H. 1997. Breaches in the boardroom: Organizational identity and conflicts of commitment in a non profit organization. Organization Science, 8(6): 593-611. http://dx.doi.org/10.1287/orsc.8.6.593

Gonin, M. 2007. Business research, self-fulfilling prophecy, and the inherent responsibility of scholars. Journal of Academic Ethics, 5(1): 33-58. http://dx.doi.org/10.1007/s10805-007-9039-3

Greenwood, R., Díaz, A. M., Li, S. X., \& Lorente, J. C. 2010. The multiplicity of institutional logics and the heterogeneity of organizational responses. Organization Science, 21(2): 521-39. http://dx.doi.org/10.1287/orsc.1090.0453 
Greenwood, R., Raynard, M., Kodeih, F., Micelotta, E. R., \& Lounsbury, M. 2011. Institutional complexity and organizational responses. Academy of Management Annals, 5(1): 317-71. http://dx.doi.org/10.1080/19416520.2011.590299

Grimes, M. 2010. Strategic sensemaking within funding relationships: The effects of performance measurement on organizational identity in the social sector. Entrepreneurship Theory and Practice, 34(4): 763-83. http://dx.doi.org/10.1111/j.1540-6520.2010.00398.x

Gutierrez, B., Howard-Grenville, J., \& Scully, M. A. 2010. The faithful rise up: Split identification and an unlikely change effort. Academy of Management Journal, 53(4): 673-99. http://dx.doi.org/10.5465/AMJ.2010.52814362

Haigh, N., \& Hoffman, A. J. 2012. Hybrid organizations: The next chapter of sustainable business. Organizational Dynamics, 41(2): 126-34.

http://dx.doi.org/10.1016/j.orgdyn.2012.01.006

Hanleybrown, F., Kania, J., \& Kramer, M. R. 2012. Channeling change: Making collective impact work. Stanford Social Innovation Review, blog entry. Available at http://www .ssireview.org/blog/entry/channeling_change_making_collective_impact_work.

Hart, K., Laville, J.-L., \& Cattani, A. D. 2010. The human economy: A citizen's guide. Cambridge: Polity Press.

Haugh, H., \& Peredo, A. M. 2010. The origins, launch and diffusion of the community interest company, Academy of Management Montreal.

Hoffman, A. J., Badiane, K. K., \& Haigh, N. 2010. Hybrid organizations as agents of positive social change: Bridging the for-profit and non-profit divide. Working paper, Ross School of Business, University of Michigan, Ann Arbor.

Hsu, G. 2006. Jacks of all trades and masters of none: Audiences' reactions to spanning genres in feature film production. Administrative Science Quarterly, 51(3): 420-50.

Jarzabkowski, P. 2008. Shaping strategy as a structuration process. Academy of Management Journal, 51(4): 621-50.

Jay, J. 2013. Navigating paradox as a mechanism of change and innovation in hybrid organizations. Academy of Management Journal, 56(1): 137-59. http://dx.doi.org/10.5465/amj.2010.0772

Jensen, M. C. 2002. Value maximization, stakeholder theory, and the corporate objective function. Business Ethics Quarterly, 12(2): 235-56. http://dx.doi.org/10.2307/3857812

2008. Non-rational behavior, value conflict, stakeholder theory and firm behavior in dialogue: Toward superior stakeholder theory. Business Ethics Quarterly, 18(2): 167-71.

Kania, J., \& Kramer, M. 2011. Collective impact. Stanford Social Innovation Review, 9(1): 36-41.

Karnani, A., Garrette, B., Kassalow, J., \& Lee, M. 2011. Better vision for the poor. Stanford Social Innovation Review, 9(2) (Spring): 66-71.

Kraatz, M. S., \& Block, E. 2008. Organizational implications of institutional pluralism. In R. Greenwood, C. Oliver, K. Sahlin, \& R. Suddaby (Eds.), The Sage handbook of organizational institutionalism: 243-75. Los Angeles: SAGE.

http://dx.doi.org/10.4135/9781849200387.n10 
Lawrence, T., Suddaby, R., \& Leca, B. 2011. Institutional work: Refocusing institutional studies of organization. Journal of Management Inquiry, 20(1): 52-58. http://dx.doi.org/10.1177/1056492610387222

Levinthal, D., \& March, J. 1993. The myopia of learning. Strategic Management Journal, 14 (Special Issue): 95-112. http://dx.doi.org/10.1002/smj.4250141009

Lewis, M. W. 2000. Exploring paradox: Toward a more comprehensive guide. Academy of Management Review, 25(4): 760-76.

Lewis, M. W., Andriopoulos, C., \& Smith, W. K. Forthcoming. Paradoxical leadership to enable strategic agility. California Management Review.

Light, P. C. 2009. Social entrepreneurship revisited: Not just anyone, anywhere in any organization can make breakthrough change. Stanford Social Innovation Review, 7(3) (Summer): 21-22.

Luscher, L., \& Lewis, M. 2008. Organizational change and managerial sensemaking: Working through paradox. Academy of Management Journal, 51(2): 221-40. http://dx.doi.org/10.5465/AMJ.2008.31767217

Mair, J., \& Martí, I. 2006. Social entrepreneurship research: A source of explanation, prediction, and delight. Journal of World Business, 41(1): 36-44. http://dx.doi.org/10.1016/j.jwb.2005.09.002

2009. Entrepreneurship in and around institutional voids: A case study from Bangladesh. Journal of Business Venturing, 24(5): 419-35.

http://dx.doi.org/10.1016/j.jbusvent.2008.04.006

Mair, J., Martí, I., \& Ventresca, M. J. 2012. Building inclusive markets in rural Bangladesh: How intermediaries work institutional voids. Academy of Management Journal, 55(4): 819-50. http://dx.doi.org/10.5465/amj.2010.0627

March, J. 1991. Exploration and exploitation in organizational learning. Organization Science, 2(1): 71-87. http://dx.doi.org/10.1287/orsc.2.1.71

Margolis, J. D., \& Walsh, J. 2003. Misery loves company: Rethinking social initiatives by business. Administrative Science Quarterly, 48(2): 268-305.

http://dx.doi.org/10.2307/3556659

Marquis, C., \& Battilana, J. 2009. Acting globally but thinking locally? The enduring influence of local communities on organizations. Research in Organizational Behavior, 29: 283-302. http://dx.doi.org/10.1016/j.riob.2009.06.001

Martin, R. 2007. The opposable mind: How successful leaders win through integrative thinking. Boston: Harvard Business School Press.

Mersland, R., \& Strom, R. Ø. 2010. Microfinance mission drift? World Development, 38(1): 28-36. http://dx.doi.org/10.1016/j.worlddev.2009.05.006

Meyer, J. W., \& Rowan, B. 1977. Institutionalized organizations: Formal structure as myth and ceremony. American Journal of Sociology, 83(2): 340-63. http://dx.doi.org/10.1086/226550

Miller, T. L., Wesley, C. L., \& Williams, D. E. 2012. Educating the minds of caring hearts: Comparing the views of practitioners and educators on the importance of social entrepreneurship competencies. Academy of Management Learning \& Education, 11(3): 349-70. http://dx.doi.org/10.5465/amle.2011.0017 
Mitchell, R. K., Agle, B. R., \& Wood, D. 1997. Toward a theory of stakeholer indentification and salience: Defining the principle of who and what really counts. Academy of Management Review, 22(4): 853-96.

Moon, J., Crane, A., \& Matten, D. 2005. Can corporations be citizens? Corporate citizenship as a metaphor for business participation in society. Business Ethics Quarterly, 15(3): 429-53. http://dx.doi.org/10.5840/beq200515329

Moss, T. W., Short, J. C., Payne, G. T., \& Lumpkin, G. T. 2011. Dual identities in social ventures: An exploratory study. Entrepreneurship Theory and Practice, 35(4): 805-30. http://dx.doi.org/10.1111/j.1540-6520.2010.00372.x

Nag, R., Corley, K. G., \& Gioia, D. A. 2007. The intersection of organizational identity, knowledge, and practice: Attempting strategic change via knowledge crafting. Academy of Management Journal, 50(4): 821-47. http://dx.doi.org/10.5465/AMJ.2007.26279173

Navis, C., \& Glynn, M. A. 2011. Legitimate distinctiveness and the entrepreneurial identity: Influence on investor judgments of new venture plausibility. Academy of Management Review, 36(3): 479-99. http://dx.doi.org/10.5465/AMR.2011.61031809

Negro, G., Kocak, O., \& Hsu, G. 2010. Research on categories in the sociology of organizations. Categories in Markets: Origins and Evolution, 31: 3-35.

Nicholls, A., \& Opal, C. 2004. Fair trade: Market-driven ethical consumption. London: Sage Publications.

Ogden, S., \& Watson, R. 1999. Corporate performance and stakeholder management: Balancing shareholder and customer interests in the U.K. privatized water industry. Academy of Management Journal, 42(5): 526-38. http://dx.doi.org/10.2307/256974

Orlitzky, M., Schmidt, F. L., \& Rynes, S. L. 2003. Corporate social and financial performance: A meta-analysis. Organization Studies, 24(3): 403-41. http://dx.doi.org/10.1177/0170840603024003910

Pache, A. C. 2013. From caring entrepreneur to caring enterprise: Addressing the ethical challenges of scaling up social enterprises. Working paper, Insead University, Fontainebleau, France.

Pache, A. C., \& Chowdhury, I. 2012. Social entrepreneurs as institutionally embedded entrepreneurs: Toward a new model of social entrepreneurship education. Academy of Management Learning \& Education, 11(3): 494-510. http://dx.doi.org/10.5465/amle.2011.0019

Pache, A. C., \& Santos, F. 2010. When worlds collide: The internal dynamics of organizational responses to conflicting institutional demands. Academy of Management Review, 35(3): 455-76. http://dx.doi.org/10.5465/AMR.2010.51142368

. Forthcoming. Inside the hybrid organization: Selective coupling as a response to conflicting institutional logics. Academy of Management Journal.

Pfeffer, J., \& Salancik, G. R. 1978. The external control of organizations: A resource dependence perspective. New York: Harper and Row.

Phillips, R. A., \& Freeman, R. E. 2008. Corporate citizenship and community stakeholders. In A. G. Scherer \& G. Palazzo (Eds.), Handbook of research on global corporate citizenship: 99-115. Cheltenham, UK: Edward Elgar. 
Poole, M. S., \& Van de Ven, A. 1989. Using paradox to build management and organizational theory. Academy of Management Review, 14(4): 562-78.

Porter, T. M. 1995. Trust in numbers: The pursuit of objectivity in science and public life. Princeton, NJ: Princeton University Press.

Powell, W. W., \& Colyvas, J. 2008. Microfoundations of institutional theory. In R. Greenwood, C. Oliver, K. Sahlin, \& R. Suddaby (Eds.), The Sage handbook of organizational institutionalism: 276-98. Los Angeles: SAGE. http://dx.doi.org/10.4135/9781849200387.n11

Prahalad, C. K. 2006. The fortune at the bottom of the pyramid. Delhi: Pearson Education India.

Pratt, M. G. 2000. The good, the bad, and the ambivalent: Managing identification among Amway distributors. Administrative Science Quarterly, 45(3): 456-93. http://dx.doi.org/10.2307/2667106

Pratt, M. G., \& Corley, K. 2007. Managing multiple organizational identities: On identity ambiguity, identity conflict, and members' reactions. In C. A. Bartel, S. Blader, \& A. Wrzesniewski (Eds.), Identity and the modern organization: 99-118. Mahwah, NJ: Lawrence Erlbaum Associates.

Pratt, M. G., \& Foreman, P. O. 2000. Classifying managerial responses to multiple organizational identities. Academy of Management Review, 25(1): 18-42.

Pratt, M. G., \& Kraatz, M. S. 2009. E pluribus unum: Multiple identities and the organizational self. In L. M. Roberts \& J. E. Dutton (Eds.), Exploring positive identities and organizations: Building a theoretical and research foundation: 385-410. New York: Psychology Press.

Pratt, M. G., \& Rafaeli, A. 1997. Organizational dress as a symbol of multilayered social identities. Academy of Management Journal, 40(4): 862-98.

Quinn, R., \& Cameron, K. 1988. Paradox and transformation: Toward a theory of change in organization and management Cambridge, MA: Ballinger.

Rothenberg, A. 1979. The emerging goddess. Chicago: University of Chicago Press.

Rowley, T. J., \& Moldoveanu, M. 2003. When will stakeholder groups act? An interest- and identity-based model of stakeholder group mobilization. Academy of Management Review, 28(2): 204-19.

Seelos, C., \& Mair, J. 2005. Social entrepreneurship: Creating new business models to serve the poor. Business Horizons, 48: 241-46. http://dx.doi.org/10.1016/j.bushor.2004.11.006

2007. Profitable business models and market creation in the context of deep poverty: A strategic view. Academy of Management Perspectives, 21(4): 49-63. http://dx.doi.org/10.5465/AMP.2007.27895339

Selznick, P. 1957. Leadership in administration. Berkeley: University of California Press.

Seo, M., \& Creed, W. 2002. Institutional contradictions, praxis, and institutional change: A dialectical perspective. Academy of Management Review, 27(2): 222-47.

Sisón, A. J. G., Hartman, E. M., \& Fontrodona, J. 2012. Reviving tradition: Virtue and the common good in business and management. Business Ethics Quarterly, 22(2): 207-10. 
Smith, K. 2002. Manna in the wilderness of AIDS: Ten lessons in abundance. Cleveland: Pilgrim Press.

Smith, K., \& Berg, D. 1987. Paradoxes of group life. San Francisco: Jossey-Bass.

Smith, W. K. 2013. Dynamic response patterns to paradoxical tensions: A model of senior leadership practices to manage ambidexterity. Working paper, University of Delaware, Newark.

Smith, W. K., Besharov, M. L., Wessels, A., \& Chertok, M. 2012. A paradoxical leadership model for social entrepreneurs: Challenges, leadership skills, and pedagogical tools for managing social and commercial demands. Academy of Management Learning \& Education, 11(3): 463-78. http://dx.doi.org/10.5465/amle.2011.0021

Smith, W. K., Leonard, H., \& Epstein, M. 2007. Digital divide data: A social enterprise in action. Harvard Business School Case Study.

Smith, W. K., \& Lewis, M. W. 2011. Toward a theory of paradox: A dynamic equilibrium model of organizing. Academy of Management Review, 36(2): 381-403. http://dx.doi.org/10.5465/AMR.2011.59330958

Smith, W. K., Lewis, M. W., \& Tushman, M. 2011. Organizational sustainability: Organization design and senior leadership to enable strategic paradox. In K. Cameron \& G. Spreitzer (Eds.), The Oxford handbook of positive organizational scholarship: 798-810. New York: Oxford University Press.

Smith, W. K., \& Tushman, M. L. 2005. Managing strategic contradictions: A top management model for managing innovation streams. Organization Science, 16(5): 522-36. http://dx.doi.org/10.1287/orsc.1050.0134

Snaith, I. 2007. Recent reforms to corporate legal structures for social enterprise in the UK: Opportunity or confusion. Social Enterprise Journal, 3(1): 20-30. http://dx.doi.org/10.1108/17508610780000719

Sonenshein, S. 2006. Crafting social issues at work. Academy of Management Journal, 49(6): 1158-72. http://dx.doi.org/10.5465/AMJ.2006.23478243

Stohl, C., \& Cheney, G. 2001. Participatory processes/paradoxical practices: Communication and the dilemmas of organizational democracy. Management Communication Quarterly, 14(3): 349-407. http://dx.doi.org/10.1177/0893318901143001

Stoltzfus, K., Stohl, C., \& Seibold, D. R. 2011. Managing organizational change: Paradoxical problems, solutions, and consequences. Journal of Organizational Change Management, 24(3): 349-67. http://dx.doi.org/10.1108/09534811111132749

Stuart, T. E., Hoang, H., \& Hybels, R. C. 1999. Interorganizational endorsements and the performance of entrepreneurial ventures. Administrative Science Quarterly, 44(2): 315-49. http://dx.doi.org/10.2307/2666998

Suchman, M. C. 1995. Managing legitimacy: Strategic and institutional approaches. Academy of Management Review, 20(3): 571-610.

Sundaramurthy, C., \& Lewis, M. 2003. Control and collaboration: Paradoxes of governance. Academy of Management Review, 28(3): 397-415.

Swartz, J. 2010. How I did it: Timberland's CEO on standing up to 65,000 angry activists. Harvard Business Review, 88(9): 39-43. 
Thompson, J. 1967. Organizations in action: Social science bases of administrative theory. New York: McGraw-Hill.

Thornton, P. H. 2002. The rise of the corporation in a craft industry: Conflict and conformity in institutional logics. Academy of Management Journal, 45(1): 81-101. http://dx.doi.org/10.2307/3069286

Thornton, P. H., Ocasio, W., \& Lounsbury, M. 2012. The institutional logics perspective: A new approach to culture, structure and process. New York: Oxford University Press.

Tracey, P. 2012. Introduction: Digital resources and textbooks for teaching social entrepreneurship and innovation. Academy of Management Learning \& Education, 11(3): 511-11. http://dx.doi.org/10.5465/amle.2012.0212

Tracey, P., \& Phillips, N. 2007. The distinctive challenge of educating social entrepreneurs: A postscript and rejoinder to the special issue on entrepreneurship education. Academy of Management Learning \& Education, 6(2): 264-71. http://dx.doi.org/10.5465/AMLE.2007.25223465

Tracey, P., Philips, N., \& Haugh, H. 2005. Beyond philanthropy: Community enterprise as a basis for corporate citizenship. Journal of Business Ethics, 58(4): 327-44. http://dx.doi.org/10.1007/s10551-004-6944-X

Tracey, P., Phillips, N., \& Jarvis, O. 2011. Bridging institutional entrepreneurship and the creation of new organizational forms: A multilevel model. Organization Science, 22(1): 60-80. http://dx.doi.org/10.1287/orsc.1090.0522

Treviño, L. K., \& Weaver, G. R. 1999. The stakeholder research tradition: Converging theorists-not convergent theory. Academy of Management Review, 24(2): 222-27.

Vince, R., \& Broussine, M. 1996. Paradox, defense and attachment: Accessing and working with emotions and relations underlying organizational change. Organization Studies, 17(1): 1-21. http://dx.doi.org/10.1177/017084069601700101

Voss, G. B., Cable, D. M., \& Voss, Z. G. 2008. Linking organizational values to relationships with external constituents: A study of nonprofit professional theatres. Organization Science, 11(3): 330-47. http://dx.doi.org/10.1287/orsc.11.3.330.12497

Wang, J., \& Dewhirst, H. D. 1992. Boards of directors and stakeholder orientation. Journal of Business Ethics, 11(2): 115-23. http://dx.doi.org/10.1007/BF00872318

Weaver, G. R., Treviño, L. K., \& Cochran, P. L. 1999. Integrated and decoupled corporate social performance: Management commitments, external pressure, and corporate ethics practices. Academy of Management Journal, 42(5): 539-52. http://dx.doi.org/10.2307/256975

Westenholz, A. 1993. Paradoxical thinking and change in frames of reference. Organization Studies, 14(1): 37-58.

Yunus, M. 1999. Banker to the poor. New York: Public Affairs.

2010. Building social business : The new kind of capitalism that serves humanity's most pressing needs. New York: PublicAffairs.

Zahra, S. A., Gedajlovic, E., Neubaum, D., \& Shulman, J. M. 2009. A typology of social entrepreneurs: Motives, search processes and ethical challenges. Journal of Business Venturing, 24(5): 519-32. http://dx.doi.org/10.1016/j.jbusvent.2008.04.007 
Zuckerman, E. 1999. The cateogrical imperative: Securities analysis and the illegitimacy discount. American Journal of Sociology, 104(5): 1398-1438. http://dx.doi.org/10.1086/210178 . 2000. Focusing the corporate product: Securities analysts and de-diversification. Administrative Science Quarterly, 45(3): 591-619. http://dx.doi.org/10.2307/2667110 